\title{
Research on agro-food sustainability transitions: where are food security and nutrition?
}

\author{
Hamid El Bilali ${ }^{1}$ (iD \\ Received: 13 April 2018 / Accepted: 10 April 2019 / Published online: 16 May 2019 \\ (C) The Author(s) 2019
}

\begin{abstract}
The main outcome of sustainable agro-food systems is food and nutrition security. Nevertheless, about half of the global population is affected by food insecurity and malnutrition, a symptom of the dysfunctions of the current food system. This paper provides a review of the state of research on the sustainability of agro-food transitions, and the extent to which and in what ways such research examines food and nutrition security. A search carried out on Scopus in January 2018 yielded 771 documents; 120 of these were included in the systematic review. Agro-food represents a small share of the sustainability transitions research field. Most of the available research focuses on crops and the production stage. In general, it is assumed that a transition to sustainability in the agro-food arena would lead to increased food availability, improved food access, better food utilisation and increased food system stability and resilience. However, scholars also point out that the quest for food security (especially through intensification) may undermine transition towards sustainable agriculture and food systems. Likewise, it is assumed that a transition towards sustainable food systems implies changes in dietary patterns and nutrition habits. Nevertheless, food security and nutrition are still marginal topics in the literature on agro-food sustainability transitions. Furthermore, transformation of food systems, which should guide agro-food sustainability transitions, is the exception rather than the rule in the research field. This systematic review represents a useful contribution to research on transitions towards sustainability in agriculture and food sectors, and provides insights into how such research can contribute to addressing the grand challenges of food insecurity and malnutrition. The paper suggests the need to move beyond silos by fostering cross-sectoral collaboration and the integration of the agro-food sustainability transitions and food security research fields.
\end{abstract}

Keywords Sustainability transitions $\cdot$ Food security $\cdot$ Nutrition $\cdot$ Food system $\cdot$ Agriculture

\section{Introduction}

Food security has an important history and represents a key concept for policymakers (Bureau and Swinnen 2018; Candel and Biesbroek 2018; Lang and Barling 2012). The food security concept has evolved and expanded over recent decades (Du and King 2018; Committee on World Food Security 2012; Gross et al. 2000; Lang and Barling 2012; McMichael 2014). The 1996 World Food Summit definition of food security (Table 1) is still widely used (FAO 1996); such a definition represented a change of focus from increasing food

Hamid El Bilali

hamid.elbilali@boku.ac.at

1 Centre for Development Research, University of Natural Resources and Life Sciences (BOKU), Peter Jordan Straße 76,

1190 Vienna, Austria production to improving food access in order to address food insecurity (Ingram 2011a). It was officially reaffirmed in the 2009 Declaration of the World Summit on Food Security (FAO 2009a, b), with the addition of social access to food. Food security is built on four pillars (Committee on World Food Security 2012; Ericksen 2008; FAO et al. 2013; United Nations System High Level Task Force on Global Food Security 2011): food availability (i.e. sufficient quantities of food available on a consistent basis); food access (i.e. having sufficient resources to obtain appropriate and nutritious foods); food use/utilisation (i.e. appropriate use, based on knowledge of basic nutrition and care); and stability in food availability, access and utilization. While food security has been mainly discussed from the angle of agriculture and markets, malnutrition has been predominantly considered as a health problem. Nutrition security (Table 1) focusses on individual/household food consumption and on how food is utilised by the body (Committee on World Food Security 
Table 1 Definitions of some concepts relating to food security and nutrition

\begin{tabular}{|c|c|c|}
\hline Concept & Definition & Reference \\
\hline \multirow[t]{2}{*}{ Food security } & $\begin{array}{l}\text { Food security exists when all people at all times have physical and economic access to sufficient, } \\
\text { safe and nutritious food to meet their dietary needs and food preferences for an active and } \\
\text { healthy life. }\end{array}$ & FAO 1996 \\
\hline & $\begin{array}{l}\text { Food security exists when all people, at all times, have physical, social and economic access to } \\
\text { sufficient, safe and nutritious food to meet their dietary needs and food preferences for an active } \\
\text { and healthy life }\end{array}$ & FAO 2009a \\
\hline \multirow[t]{2}{*}{$\begin{array}{l}\text { Nutrition } \\
\text { Security }\end{array}$} & $\begin{array}{l}\text { Nutrition security can be defined as adequate nutritional status in terms of protein, energy, } \\
\text { vitamins, and minerals for all household members at all times. }\end{array}$ & $\begin{array}{l}\text { IFPRI } 1995 \text { in Committee on } \\
\text { World Food Security } 2012\end{array}$ \\
\hline & $\begin{array}{l}\text { Nutrition security exists when food security is combined with a sanitary environment, adequate } \\
\text { health services, and proper care and feeding practices to ensure a healthy life for all household } \\
\text { members. }\end{array}$ & $\begin{array}{l}\text { World Bank } 2006 \text { in Committee on } \\
\text { World Food Security } 2012\end{array}$ \\
\hline \multirow[t]{2}{*}{$\begin{array}{l}\text { Food and } \\
\text { nutrition } \\
\text { security }\end{array}$} & $\begin{array}{l}\text { Food and nutrition security is achieved when adequate food (quantity, quality, safety, socio-cultural } \\
\text { acceptability) is available and accessible for and satisfactorily used and utilized by all individ- } \\
\text { uals at all times to live a healthy and active life. }\end{array}$ & $\begin{array}{l}\text { UNICEF } 2008 \text { in Committee on } \\
\text { World Food Security } 2012\end{array}$ \\
\hline & $\begin{array}{l}\text { Food and nutrition security exists when all people at all times have physical, social and economic } \\
\text { access to food of sufficient quantity and quality in terms of variety, diversity, nutrient content } \\
\text { and safety to meet their dietary needs and food preferences for an active and healthy life, } \\
\text { coupled with a sanitary environment, adequate health, education and care. }\end{array}$ & $\begin{array}{l}\text { FAO } 2011 \text { in Committee on World } \\
\text { Food Security } 2012\end{array}$ \\
\hline
\end{tabular}

2012). Food security and nutrition security have generally been combined in two different ways, i.e. food security and nutrition, or food and nutrition security (Table 1). Both terms acknowledge the importance of addressing key nutritional concerns for achieving food security and emphasise the need for greater integration of nutrition into food security programmes and policies (Committee on World Food Security 2012). Until recently, most food-related policies and interventions, especially those related to agriculture, were rarely designed with nutrition as their primary objective or their primary concern (Allen and de Brauw 2018; FAO 2013; Poole et al. 2018; UNSCN 2016; Thow et al. 2018). Nevertheless, food security is essential to ensuring adequate nutrition, and the two concepts - food security and nutrition security - are interlinked and overlap (FAO 2013, 2017).

It is increasingly understood that attaining food security is more complicated than just producing more food, as the fundamental issue concerns access to nutritious and safe food (Dumont and Rosier 1969; George 1976; OECD 2013; Prosekov and Ivanova 2018; Sen 1981). Therefore, attention has turned to food systems and their functioning, governance and sustainability (Delaney et al. 2018; El Bilali 2018a; Ingram 2011a, b; Marsden et al. 2018). In fact, the dimensions of food security are highly influenced by food system activities (Beddington et al. 2012; Foresight 2011; Garnett 2014; Godfray et al. 2010; HLPE 2014a). The importance of a systems approach for the achievement of food and nutrition security (FNS) was stressed by the High Level Panel of Experts on Food Security and Nutrition (HLPE) in its note on critical and emerging issues for food security and nutrition (HLPE 2014b). In July 2014, the Panel provided the following definition of a sustainable food system (HLPE 2014a): " $A$ sustainable food system (SFS) is a food system that delivers food security and nutrition for all in such a way that the economic, social and environmental bases to generate food security and nutrition for future generations are not compromised" (p. 31), where "A food system gathers all the elements (environment, people, inputs, processes, infrastructures, institutions, etc.) and activities that relate to the production, processing, distribution, preparation and consumption of food and the outputs of these activities, including socioeconomic and environmental outcomes" (HLPE 2014a:29). According to FAO (2014), there is an unprecedented confluence of pressures on modern agriculture and food systems. In fact, the current food systems lie at the centre of a global nexus of environmental, social and economic problems, as the world faces the challenge of achieving sustainable food security in the face of resource scarcity, ecosystem degradation, human population growth, and climate change (FAO 2014; Foresight 2011; Garnett 2014; Gladek et al. 2016; Godfray et al. 2010b; IPES-Food 2015; Lang 2009; Searchinger et al. 2013; Vermeulen et al. 2012; World Bank 2015; WWW-UK 2013). Moreover, modern agro-food systems have failed in addressing the issues of food insecurity and malnutrition (FAO et al. 2015, 2017; Foresight 2011; Godfray et al. 2010a; WWW-UK 2013).

Agriculture, food security, nutrition and sustainability are increasingly discussed in the same context (e.g. Allen and de Brauw 2018; Fanzo et al. 2018; Lang 2009; Willett et al. 2019; Yates et al. 2018). In fact, recent global processes and debates have emphasised the importance of food security as part of sustainability, and vice versa (Berry et al. 2015; Prosperi et al. 2014). The definition of a sustainable food system provided by HLPE (2014a) clearly shows the strong linkage between 
food security and food sustainability; food systems unsustainability is a key driver of food insecurity and malnutrition. The definition also highlights the importance of addressing environmental, economic and social dimensions of sustainability simultaneously, at every stage of a food system. Likewise, there has been increasing agreement among scholars and practitioners that sustainability is very relevant to food security (Garnett et al. 2013; Hanson 2013; Lang and Barling 2013; Pinstrup-Andersen and Herforth 2008; Richardson 2010; Smith and Gregory 2013; UNEP 2012). Environmental, economic and social sustainability are, indeed, preconditions for long-term food security (Berry et al. 2015) and are applicable across all dimensions of sustainability (Gitz 2015). However, the relationships between food security and food sustainability are reciprocal, as food security is increasingly also considered a condition for sustainability (Berry et al. 2015). That's why Garnett (2014) considers both food system sustainability and sustainable food security, and identifies three prominent perspectives on how to achieve them (cf. efficiency, demand restraint, food system transformation). Similarly, the 'New nutrition science' (Anonymous 2005; Leitzmann and Cannon 2005) incorporates a more comprehensive understanding of the relation between food systems sustainability and good nutrition. In fact, in The Giessen Declaration (Anonymous 2005), "Nutrition science is defined as the study of food systems, foods and drinks, and their nutrients and other constituents; and of their interactions within and between all relevant biological, social and environmental systems" (p. 786). Sustainability of food systems is also considered a prerequisite for achieving improved nutrition, as in the Rome Declaration on Nutrition (FAO and WHO 2014) and the Framework for Action of the Second International Conference on Nutrition (ICN2) (UNSCN 2017). Linkages between good nutrition and sustainable food systems are also highlighted in the HLPE report entitled 'Nutrition and food systems' (HLPE 2017).

Over the last decades, there has been an increasing focus on the conceptual development and identification of trajectories that move societies toward sustainability. Therefore, the concept of 'transition' (Gazheli et al. 2012; Loorbach and Rotmans 2010), as well as the field of transition studies, has recently received increasing attention both in the policy arena and in academic literature (European Environment Agency 2016; Falcone 2014; Lachman 2013; Markard et al. 2012; STRN 2017). In this context, the notion of 'transition' gained wider recognition in research on agriculture (e.g. Elzen et al. 2017) and food systems (e.g. Hinrichs 2014) over the past decade. The characteristics of sustainability problems imply that incremental changes are no longer sufficient, and there is a need for transformative change at the systems level (STRN 2010). Therefore, the notion of 'sustainability transition' (Markard et al. 2012) was coined to embrace the goal of transition to sustainable systems (Lachman 2013), including food systems. Markard et al. (2012) define sustainability transitions as "long-term, multi-dimensional and fundamental transformation processes through which established socio-technical systems shift to more sustainable modes of production and consumption" (p. 956). Different frameworks are used in transition studies; Lachman (2013) provides a review of the more prominent ones, i.e. Multi-Level Perspective (Geels 2002, 2011), Strategic Niche Management (Raven and Geels 2010; Schot and Geels 2008), Transition Management (Loorbach and Rotmans 2006; Loorbach et al. 2008; Loorbach 2010) and Technological Innovation Systems (Bergek et al. 2008; Hekkert et al. 2007). El Bilali (2018b) reviews the use of the most prominent transition frameworks (Multi-Level Perspective, Transition Management, Strategic Niche Management, Technological Innovation Systems, Social Practice Approach) in research on agro-food sustainability transitions.

Earlier work on sustainability transitions tended to focus on energy and mobility systems while overlooking agro-food systems (Hinrichs 2014; Markard et al. 2012; Sustainability Transitions Research Network 2018; Truffer and Markard 2017). Agro-food sustainability transitions, i.e. sustainability transitions in agro-food systems, refer to long-lasting sociotechnical transformation processes that guide food practices towards sustainability (Costa 2013). According to Spaargaren et al. (2013), food transitions refer to structural change processes that give rise to new production and consumption modes and to practices that are more sustainable. Agro-food sustainability transitions are processes of change in established patterns of agro-food production, processing, distribution and consumption.

Although food system sustainability, and food security and nutrition are strongly linked, scientific discussion on food system sustainability often stayed separated from the discourse on food security (e.g. Capone et al. 2014). Transition to sustainable agro-food systems is the objective of many initiatives in the agro-food arena (e.g. UNEP 2018) and a focus of a growing body of literature on agro-food sustainability transitions (Maye and Duncan 2017; Spaargaren et al. 2013). However, it is unclear whether such a literature pays due attention to the linkages between sustainable food systems, and food security and nutrition. Therefore, the present paper analyses the approach to food security and nutrition in research on agro-food sustainability transitions.

The paper is structured as follows: section 2 describes the methodology used; section 3 presents the metrics of research on agro-food sustainability transitions; and section 4 analyses whether and how research on agro-food sustainability transitions addresses food security and nutrition. Section 4 also sheds light on the perspectives (efficiency, demand-restraint, food system transformation) that guide approaches to food security in the literature on agro-food sustainability transitions. 


\section{Material and methods}

The paper draws upon a systematic review of documents indexed in the Scopus database (Fig. 1). The methodology used for the selection of documents included in the systematic review is similar to that adopted by El Bilali (2018b). The literature search was carried out on January 22nd, 2018, using the Title-Abs-Key search query: (transition AND sustainability) AND (agri* OR food). The search yielded 771 documents. To these were added 56 records dealing with agriculture and/ or food from the publications announcement section of the trimestral newsletter of the Sustainability Transitions Research Network (STRN). The total number of records after duplicates (44 records) were removed was 783 .

Following the review of titles, a further 118 documents were excluded, as they did not deal with sustainability transitions and/or with agro-food. In case of doubt, records were kept for further analysis.

An additional 511 records were excluded following a screening of abstracts. Particular attention was paid to how the search query words (i.e. transition, sustainability, agri, food) were used in abstracts. Records referring to political or economic transitions (especially in Eastern Europe and the former Soviet Union) without any particular focus on agrofood were excluded. Records excluded at this stage included conference announcements in some journals (e.g. Proceedings of the Nutrition Society, International Journal of Life Cycle Assessment, Journal of Environmental Radioactivity), records with no other name available (e.g. proceedings) and book chapters. At this point, 111 documents dealing with agri-food were directly added to "Selected documents" list as they referred explicitly to the use of a transition framework. Documents addressing changes in forest management or land use, without any direct link to agriculture and/or food, were excluded. In some cases, it was clear that the paper addressed sustainability transitions but not clear whether it dealt with agro-food; in these cases, scrutiny of full papers was necessary.

A further step in the systematic review was the analysis of 43 full papers to make sure that they addressed agro-food sustainability transitions. At this stage, an additional 22 documents were excluded because they dealt only with sustainability (and sustainability assessment) in agro-food as opposed to the element that distinguishes sustainability transitions research from other sustainability research areas, namely its focus on the dynamics of system change, which includes radical innovation in its various forms, associated struggles and wide sectoral transformations. At this step (i.e. scrutiny of 43 full papers), citation of at least one of 20 core papers on transitions identified by Markard et al. (2012) was adopted as a further selection criterion.

Only original research papers were considered; 12 reviews (Cumming et al. 2014; Dentoni et al. 2017; Ferguson and Lovell 2014; Fischer et al. 2012; Gaziulusoy 2015; Kovács 2011; Libert 1997; Pereira et al. 2015; Termeer and Dewulf 2012; Wigboldus et al. 2016), as well as an editorial for a special issue of Sociologia Ruralis titled "Understanding Sustainable Food System Transitions: Practice, Assessment
Fig. 1 Systematic review process. Source: Adapted from Moher et al. (2009)

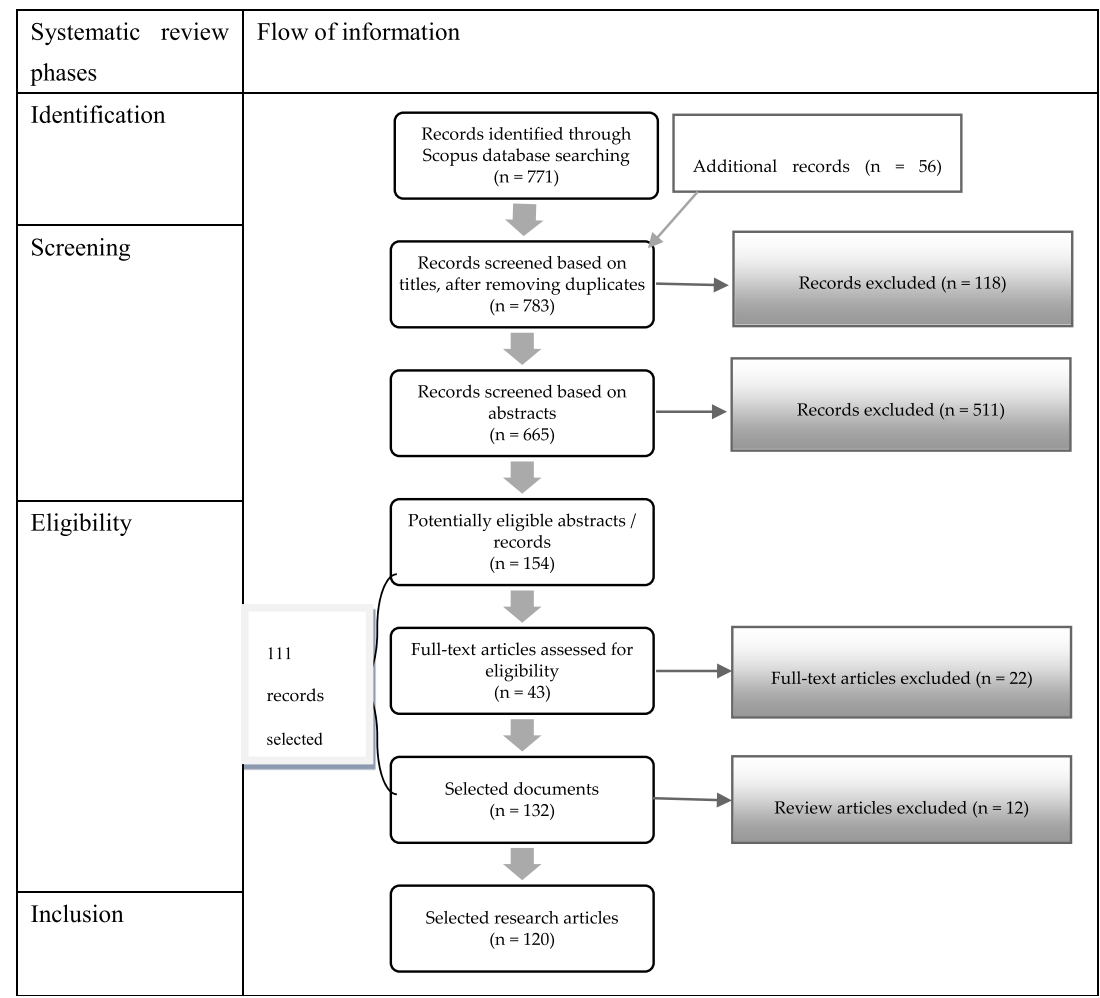


and Governance" (Maye and Duncan 2017) and an assessment (Friedmann 2017), were not included in further analysis.

Therefore, only 120 research articles (Table 2) were included in the systematic review and underwent metrical and other analyses.

The selected research papers, were first analysed for any reference to 'food security' (search string: \{food security\} OR "food availability" OR "food supply" OR "food access" OR "food utilization" OR "food use") or "nutrition' (search string: nutrition OR diet OR "food utilization" OR "food use" OR \{consumption pattern\}) in the title, abstract and/or keywords, and then for the ways in which food security and/or nutrition were addressed in the paper body, if any. In the case of papers dealing with food security, the dimensions of food security (i.e. availability, access, utilization, stability) addressed and the perspective adopted were analysed. According to Garnett (2014), three broad perspectives on how to achieve sustainable food security and food system sustainability are emerging (Table 3).

The selected records were interrogated to see which perspective identified by Garnett (2014) guided their approaches to food security (Table 4).

\section{Metrics of research on agro-food sustainability transitions}

\subsection{Agro-food in the sustainability transitions research field}

It is important to note that research on agro-food sustainability transitions is rather recent; the first paper that can be considered as an entry in that field was published in 2003 (Wiskerke 2003). In December 2016, the 22nd newsletter of the Sustainability Transitions Research Network (STRN 2016) highlighted that - using the search method of Markard et al. (2012) - there are currently about 250 new papers on sustainability transitions every year. The total is now close to 2000 . The present systematic review confirms the marginality of research on agro-food sustainability transitions in the sustainability transitions field. In fact, the maximum annual number of papers on agro-food sustainability transitions is 31 (2017), which represents only $12.4 \%$ of the papers on sustainability transitions published yearly. Nevertheless, this figure is much higher than that reported by Markard et al. (2012) who found that, as of early 2012 , only $3 \%$ of papers on sustainability

Table 2 Selected research articles dealing with agro-food sustainability transitions

\begin{tabular}{|c|c|c|}
\hline Year & $\begin{array}{l}\text { Records } \\
\text { number }\end{array}$ & References \\
\hline 2018 & 7 & $\begin{array}{l}\text { Gorissen et al. 2018; Hassink et al. 2018; Järnberg et al. 2018; Long et al. 2018; Maye } 2018 \text {; Nygaard and Bolwig } 2018 \text {; Sixt et al. } \\
2018\end{array}$ \\
\hline 2017 & 31 & $\begin{array}{l}\text { Alrøe et al. 2017; Audet et al. 2017; Bonomi et al. 2017; Crivits et al. 2017; Cross and Ampt 2017; de Olde et al. 2017; } \\
\text { Dedeurwaerdere et al. 2017; Fauchald et al. 2017; Hansen and Bjørkhaug 2017; Hauser and Lindtner 2017; Hubeau et al. 2017; } \\
\text { Huttunen and Oosterveer 2017; Isgren and Ness 2017; Jacobs et al. 2017; Kuhmonen 2017; Kuokkanen et al. 2017; Loconto and } \\
\text { Barbier 2017; Marco et al. 2017; Meynard et al. 2017; Miles et al. 2017; Paddock 2017; Partzsch 2017; Randelli and Rocchi 2017; } \\
\text { Rodríguez Morales and Rodríguez López 2017; Rosin et al. 2017; Rossi 2017; Turner et al. 2017; van den Heiligenberg et al. 2017; } \\
\text { Vivero-Pol 2017; Vlahos et al. 2017; Wonneck and Hobson 2017 }\end{array}$ \\
\hline 2016 & 25 & $\begin{array}{l}\text { Bui et al. 2016; Clear et al. 2016; Davidson et al. 2016; Ely et al. 2016; Elzen and Bos 2016; Ferguson 2016; Hammond Wagner et al. } \\
\text { 2016; Hermans et al. 2016; Hoppe et al. 2016; Jurgilevich et al. 2016; Langendahl et al. 2016; Liu et al. 2016; Long et al. 2016; } \\
\text { Maru et al. 2016; Meek 2016; Moraine et al. 2016; Mylan et al. 2016; Pant 2016; Papachristos and Adamides 2016; Pitt and Jones } \\
\text { 2016; Prasad 2016; Schut et al. 2016; Stahlbrand 2016; Vankeerberghen and Stassart 2016; Chiffoleau et al. } 2016\end{array}$ \\
\hline 2015 & 17 & $\begin{array}{l}\text { Cohen and Ilieva 2015; Davies and Doyle 2015; Ghaffari et al. 2015; Gilioli et al. 2015; Halbe et al. 2015; Ingram 2015; Ingram et al. } \\
\text { 2015; Konefal 2015; Levidow 2015; Moragues-Faus and Morgan 2015; O’Rourke and Lollo 2015; Santhanam-Martin et al. 2015; } \\
\text { Sutherland et al. 2015; Twine 2015; Tyfield et al. 2015; van Gameren et al. 2015; Vittersø and Tangeland } 2015\end{array}$ \\
\hline 2014 & 15 & $\begin{array}{l}\text { Beers et al. 2014; Bush and Marschke 2014; Davies 2014; Duru et al. 2014; Hassink et al. 2014; Hinrichs 2014; Levidow et al. 2014; } \\
\text { Minh et al. 2014; Morrissey et al. 2014; Pant 2014; Pant et al. 2014; Raman and Mohr 2014; Sherwood and Paredes 2014; } \\
\text { Slingerland and Schut 2014; Vinnari and Vinnari } 2014\end{array}$ \\
\hline 2013 & 10 & $\begin{array}{l}\text { Bhattarai and Pant 2013; Crivits and Paredis 2013; Gonzalez de Molina 2013; Hargreaves et al. 2013; Hassink et al. 2013; Hermans } \\
\text { et al. 2013; Immink et al. 2013; Lutz and Schachinger 2013; Marsden 2013; Van Mierlo et al. } 2013\end{array}$ \\
\hline 2012 & 5 & das Chagas Oliveira et al. 2012; Grin 2012; Lawhon and Murphy 2012; Manuel-Navarrete and Gallopín 2012; Zwartkruis et al. 2012 \\
\hline 2011 & 4 & Elzen et al. 2011; Jehlička and Smith 2011; Levkoe 2011; Quist et al. 2011 \\
\hline 2010 & 1 & Beers et al. 2010 \\
\hline 2009 & 2 & Negi et al. 2009; Schandl et al. 2009 \\
\hline 2008 & 1 & Lebel et al. 2008 \\
\hline 2007 & 1 & Smith and Jehlička 2007 \\
\hline 2003 & 1 & Wiskerke 2003 \\
\hline
\end{tabular}


Table 3 Three perspectives on how to achieve food system sustainability and sustainable food security

\begin{tabular}{|c|c|c|c|}
\hline Perspective & Efficiency & Demand restraint & Food system transformation \\
\hline Focus & Changes in production & Changes in consumption & $\begin{array}{l}\text { Changes in food system functioning and } \\
\text { governance }\end{array}$ \\
\hline Rationale & $\begin{array}{l}\text { This perspective focuses on changing } \\
\text { patterns of production. In the efficiency } \\
\text { mindset, the onus is on producers to } \\
\text { develop appropriate techniques and } \\
\text { strategies to reduce environmental } \\
\text { impacts while increasing productivity. }\end{array}$ & $\begin{array}{l}\text { This perspective focuses on reducing } \\
\text { excessive consumption. From the } \\
\text { demand restraint perspective, the } \\
\text { problem lies with the consumer and with } \\
\text { the companies that promote } \\
\text { unsustainable consumption patterns. } \\
\text { Excessive consumption is considered the } \\
\text { leading cause of environmental crisis. }\end{array}$ & $\begin{array}{l}\text { This perspective considers both } \\
\text { consumption and production in terms of } \\
\text { the relationships among food system } \\
\text { actors, interpreting the problem as one of } \\
\text { imbalance, social injustice or inequality. }\end{array}$ \\
\hline Food security & $\begin{array}{l}\text { Food security problem is a supply side } \\
\text { (availability) challenge }\end{array}$ & $\begin{array}{l}\text { There is enough food to feed everyone. The } \\
\text { challenges are resource-intensive con- } \\
\text { sumption patterns and diets. }\end{array}$ & $\begin{array}{l}\text { All four food security dimensions are } \\
\text { considered }\end{array}$ \\
\hline
\end{tabular}

Source: Adapted from Garnett (2014)

transitions indexed in the Scopus database dealt with food, far behind energy (36\% of all papers), transportation $(8 \%)$, and water and sanitation (7\%). In 2016, a large share of the 250 papers on sustainability transitions were published in journals dealing mainly with energy (STRN 2016), whilst during the 8th International Sustainability Transitions Conference (1821 June 2017; Gothenburg, Sweden), there was no track or session devoted to food. All these findings confirm the marginality of research on transitions towards sustainability in the agro-food arena. Nevertheless, there is a general trend towards an increase in contributions on agro-food sustainability transitions (from one paper per year before 2010 to 31 in 2017). Given the upward trend observed, the number of papers on agro-food sustainability transitions published in 2018 may be even higher than in 2017.

\subsection{Topical focus of research on agro-food sustainability transitions}

Many of the selected papers deal with sustainability transitions in crop production. In fact, the majority deals with the production of crops, but an increasing number of documents also focus on animal production (Davidson et al. 2016; de Olde et al. 2017; Elzen et al. 2011; Elzen and Bos 2016; Immink et al. 2013; Van Mierlo et al. 2013) or fisheries/ aquaculture (Bush and Marschke 2014; Lebel et al. 2008). However, the two last agriculture sub-sectors (animal production and fisheries/aquaculture) are largely underserved. Some papers analyse sustainability transitions in the context of croplivestock integration (Moraine et al. 2016). In the case of crop production, transitions towards organic agriculture (Ghaffari et al. 2015; Hauser and Lindtner 2017; Vittersø and Tangeland 2015) and agroecology (Cross and Ampt 2017; Duru et al. 2014; Gonzalez de Molina 2013; Isgren and Ness 2017; Levidow 2015; Levidow et al. 2014; Meek 2016; Miles et al. 2017; Pant 2016) are prominent case studies. Interestingly, there are also some papers that deal with urban/peri-urban agriculture (Gilioli et al. 2015) and urban food systems (Chiffoleau et al. 2016; Cohen and Ilieva 2015; Gorissen et al. 2018; Moragues-Faus and Morgan 2015).

Similarly, production (generally referring to crop production) is the most-addressed stage of the food chain, but there are some papers that deal with processing (Long et al. 2018; Wiskerke 2003), distribution and food procurement (Audet et al. 2017; Randelli and Rocchi 2017; Stahlbrand 2016), consumption (Clear et al. 2015, 2016; Davies 2014; Davies and Doyle 2015; Dedeurwaerdere et al. 2017; Liu et al. 2016; O'Rourke and Lollo 2015; Twine 2015) and food waste (Wonneck and Hobson 2017). Other papers adopt a 'food system' approach and address different stages of the food chain simultaneously (Alrøe et al. 2017; Bui et al. 2016; Ely et al. 2016; Hinrichs 2014; Hubeau et al. 2017; van Gameren et al. 2015; Zwartkruis et al. 2012).

Some papers deal with the intersection between agriculture and energy (Hansen and Bjørkhaug 2017; Nygaard and

Table 4 Search queries used in analysing perspectives on food security in the agro-food sustainability transitions literature

\begin{tabular}{ll}
\hline Perspective & Search query \\
\hline Efficiency & (produc* OR agri*) AND (efficien* OR intensification OR productiv*) \\
$\begin{array}{l}\text { Demand-restraint } \\
\text { Food system transformation }\end{array}$ & (consum* OR diet OR nutrition) AND (demand OR waste OR obesity) \\
& (produc* OR agri*) AND (consum* OR diet OR nutrition) AND ("food system" OR governance OR power \\
\hline
\end{tabular}


Bolwig 2018; Partzsch 2017; Raman and Mohr 2014; Rodríguez Morales and Rodríguez López 2017; Sutherland et al. 2015) or water (Sixt et al. 2018), as well as the waterenergy-food nexus (Halbe et al. 2015). In other cases, the focus is on transitions in the use of some agricultural inputs, such as fertilisers (Hoppe et al. 2016; Huttunen and Oosterveer 2017; Jacobs et al. 2017) and pesticides (Hammond Wagner et al., 2016; Sherwood and Paredes 2014).

\subsection{Metrics of agro-food sustainability transitions research field}

Metrics (sources/journals, subject areas, authors, affiliation institutions, affiliation countries, citations) for research dealing with agro-food sustainability transitions are presented in Table 5.

Sustainability (12 papers) is by far the most prominent journal when it comes to scholarly publications on agro-food sustainability transitions. It is followed by the Journal of Cleaner Production (nine papers), Journal of Rural Studies (six papers) and Technological Forecasting and Social Change (six papers). This shows that so far, no journal has specialised in publishing papers on agro-food sustainability transitions. When one looks into the number of articles published, there are some differences with respect to the prominence of journals in the overall field of sustainability transitions. In the case of the sustainability transitions research field, the most prominent journals are the Journal of Cleaner Production, Environmental Innovation and Societal Transitions, Renewable and Sustainable Energy Reviews, Energy Research and Social Science and Futures (STRN 2016). Agro-food sustainability research is conducted largely in the domains of the social sciences (69 papers), environmental science (56 papers) and, naturally, agricultural and biological sciences (33 papers). However, the area of energy research (33 papers) also figures prominently; that might be due to the fact that many papers address the interface between agriculture and energy (e.g. biofuels). Selected papers can be categorized in many subject areas (these include even psychology, the humanities, computer science, biochemistry and medicine), which may explain the difficulty of grasping the field of agrofood sustainability transitions, as such research is rather multidisciplinary.

The authors that contributed the most to the development of agro-food sustainability transitions research field are John Grin (four papers) and Frans Hermans (four papers). Meanwhile, the most influential publications in the field, in terms of citations, are 'Socio-technical regimes and sustainability transitions: Insights from political ecology' (Lawhon and Murphy 2012), with 116 citations; 'From post-productionism to reflexive governance: Contested transitions in securing more sustainable food futures' (Marsden 2013), with 59 citations; and

Table 5 Metrics of research on agro-food sustainability transitions: top-ten journals, subject areas, authors, affiliations, countries and papers (in terms of citation numbers)

Journals (a)

Subject areas (b)

Authors (c)

Affiliations (d)

Affiliation Countries (e)

Citations (f)
Sustainability Switzerland (12); Journal of Cleaner Production (9); Journal of Rural Studies (6); Technological Forecasting and Social Change (6); Agroecology and Sustainable Food Systems (5); Agricultural Systems (4); Ecological Economics (4); Environment and Planning (4); Sociologia Ruralis (4)

Social sciences (69); environmental science (56); agricultural and biological sciences (33); energy (33); business, management and accounting (25); engineering (12); economics, econometrics and finance (11); psychology (8); decision sciences (4)

John Grin (4); Frans Hermans (4); Jan Hassink (3); Wim Hulsink (3); Laurens Klerkx (3); Laxmi Prasad Pant (3)

WUR (22); Erasmus University Rotterdam (6); Open University (5); Cardiff University (5); University of Amsterdam (4); University of Guelph (4); University of Twente (4)

Netherlands (27); United Kingdom (24); United States (12); Canada (11); Belgium (9);

France (7); Finland (6); Germany (6); Australia (5); Italy (5); New Zealand (5)

Lawhon and Murphy 2012: Socio-technical regimes and sustainability transitions: Insights from political ecology (116)

Marsden 2013: From post-productionism to reflexive governance: Contested transitions in securing more sustainable food futures (59)

Elzen et al. 2011: Normative contestation in transitions 'in the making': Animal welfare concerns and system innovation in pig husbandry (57)

Quist et al. 2011: The impact and spin-off of participatory backcasting: From vision to niche (51)

Levkoe 2011: Towards a transformative food politics (49)

Hargreaves et al. 2013: Up, down, round and round: Connecting regimes and practices in innovation for sustainability (46)

Wiskerke 2003: On promising niches and constraining sociotechnical regimes: The case of Dutch wheat and bread (44)

Smith and Jehlička 2007: Stories around food, politics and change in Poland and the Czech Republic (34)

Gonzalez de Molina 2013: Agroecology and politics. How to get sustainability? About the necessity for a political agroecology (30)

Hinrichs 2014: Transitions to sustainability: A change in thinking about food systems change? (29)

Legend: Figures in brackets refer to number of documents by journal (a), subject area (b), author (c), affiliation (d), country (e); or number of citations per paper (f), as of February 22, 2018

WUR Wageningen University and Research 
"Normative contestation in transitions "in the making": Animal welfare concerns and system innovation in pig husbandry' (Elzen et al. 2011), with 57 citations.

The analysis of author affiliations suggests that research on agro-food sustainability transitions is performed mainly in European institutions and research centres, especially Dutch and British ones. The Wageningen University and Research Centre - WUR (22 papers), Erasmus University Rotterdam (six papers), Open University (five papers) and Cardiff University (five papers) are major contributors. It should be noted that almost $20 \%$ of papers dealing with this topic have at least one author affiliated with WUR, which can be considered a leader in this research field. It comes as no surprise that the list of affiliation countries is dominated by the Netherlands (27 papers) and the United Kingdom (24 papers). North America (United States - 12 papers; Canada - 11 papers) is also highly placed on the list of top-ten countries. Unfortunately, although such a list also features some countries from the Global South (e.g. Argentina, Brazil, Burundi, China, Ecuador, Ethiopia, India, Nepal, Nigeria, Peru, Thailand, Vietnam), it confirms the North-South gap in sustainability transitions research. In fact, sustainability transition studies are still largely flavoured by the context in which they were conceived, i.e. in so-called developed countries (Lachman 2013; Wieczorek 2018).

\section{Food security and nutrition in research on agro-food sustainability transitions}

Food security and nutrition are still marginal topics in research on agro-food sustainability transitions. In fact, only $21.7 \%$ and $13.3 \%$ of papers on agro-food sustainability transitions address food security and nutrition, respectively. Meanwhile, only nine out of the 120 selected research papers address both food security and nutrition (Table 6).

How the literature on agro-food sustainability transitions addresses, qualitatively, food security, nutrition, and food security and nutrition is analysed hereafter.

\subsection{Food security}

Most of the papers examined in the initial screening refer to 'food security' in their introductions, but do so only to highlight the need for sustainability transitions, and do not analyse any of the impacts of agro-food sustainability transitions in terms of food security. Only a few papers address the relation between agro-food sustainability transitions (and agro-food sustainability in general) and food security. Their perspectives, which are not mutually exclusive, can be related to the four dimensions of food security. In general, it is assumed that transition towards sustainability in the agro-food arena would affect food availability (e.g. Ely et al. 2016; Jurgilevich et al. 2016; Kuokkanen et al. 2017; Levidow 2015; Pant 2014; Pant 2016), food access (e.g. Audet et al. 2017; Kuokkanen et al. 2017), food utilisation (e.g. Davies 2014; Ely et al. 2016; Jurgilevich et al. 2016) or stability (e.g. Marsden 2013) either positively or negatively. While most of the papers focus on the implications of sustainability transitions for food security (i.e. how transition towards sustainability affects food security and its dimensions), some papers adopt a reverse approach and highlight how the quest for food security (especially through agricultural production intensification) may undermine efforts to make transitions toward sustainable agriculture and food systems (e.g. Audet et al. 2017). Therefore, discussion of the relation between food security and food system sustainability often implies an analysis of the role of innovation (both technical/technological and social) and/or of alternative forms of agriculture, such as agroecology (e.g. Pant 2014). Efforts to tackle food insecurity issues may also trigger transitions to or introductions of more environmentally-friendly forms of agriculture, such as organic farming (e.g. Hauser and Lindtner 2017). What all the selected papers highlight is the interconnection between food security and food system sustainability. Furthermore, transitions in the wider economy - the circular economy or the bio-economy, for example - (e.g. Jurgilevich et al. 2016; Levidow 2015) as well as in other sectors such as energy (e.g. Raman and Mohr 2014) have food security implications.

Audet et al. (2017) analysed the contribution of the Montreal seasonal food markets to food security and food system sustainability. They note that seasonal markets sell fresh fruits and vegetables directly to consumers in areas where food security is considered a problem, and connect transitions to sustainability in urban food systems to food security outcomes. They also highlight a tension between food security and ecological agriculture (e.g. organic agriculture) in the seasonal markets model - that is to say, the challenge of

Table 6 Food security and nutrition in research on agro-food sustainability transitions

\begin{tabular}{llll}
\hline Topic & $\begin{array}{l}\text { Records identified through } \\
\text { the search }\end{array}$ & $\begin{array}{l}\text { Records selected after } \\
\text { eligibility check }\end{array}$ & $\begin{array}{l}\text { Percentage of selected records out of research } \\
\text { articles dealing with agro-food sustainability transitions }\end{array}$ \\
\hline Food security & 55 & 26 & $21.7 \%$ \\
Nutrition & 34 & 16 & $13.3 \%$ \\
Both (food security \& nutrition) & 22 & 9 & $7.5 \%$ \\
\hline
\end{tabular}


balancing agro-food availability and affordability with sustaining local agriculture. Ely et al. (2016) discuss the effects of transition in practices and politics on the sustainability of maize production and consumption patterns in China. In particular, they compare the agricultural intensification pathway with another pathway focusing on agro-ecological approaches and green food chains. According to them, the latter pathway offers the potential of low carbon and climateresilient food security while also enabling the retention of control of agri-food systems at the community level (cf. food sovereignty). Hauser and Lindtner (2017) relate the emergence of organic agriculture in post-war Uganda, inter alia, to food insecurity; food insecurity was one of the drivers of organic agriculture development after two decades of civil war ending in 1986. Organic agriculture-based on low-cost, resource-conserving technologies and agronomic practiceswas a response to and a 'coping strategy' for the multiple crises (including food insecurity) faced by rural Ugandan households in the post-war period.

Pant (2014) provides a critical examination of food security strategies in India and Nepal that aim to enable transitions towards agricultural sustainability by transforming traditional subsistence agriculture in the two countries. He notes that both strategies rely, to a large extent, on technological innovations, and fail to valorise agro-ecological resources and natural resource-based competitive advantages. According to Pant (2014) this confirms that technological innovation (see also transition processes that are based only on a constellation of technological innovations) is not sufficient to achieve sustainable food security. In another paper, the same author (Pant 2016) analyses the paradox of mainstreaming agroecology for food security in developing countries. While the paradox is more about the impact of the mainstreaming process on the very nature and values of agroecology (see, agro-ecological niche innovations in water and soil conservation, crop intensification and improvement, and market differentiation), the paper also explores the effects of agroecological transitions on food security, especially in rural areas.

While many of the selected papers address the availability, access and utilisation dimensions of food security, Marsden (2013) is perhaps the only one who relates agro-food sustainability transitions in the UK to the stability pillar of food security (see, prices volatility). In fact, he applies a transition perspective to critically assess the turbulent period in agrofood markets since the food price spikes in 2007-8. The analysis shows that food insecurity is also an actual issue in the foodscape of a developed country such as the UK, although "Food security seems a singularly odd term to be employed in a nation beset by health-related problems of the overconsumption of food" (p. 126).

Other papers address the relation between transitions in the economy or other sectors (e.g. energy) and food security. For instance, Jurgilevich et al. (2016) provide a useful analysis of the effects of the transition toward a circular economy on food system sustainability, as well as of its implications in terms of food security. What makes their analysis interesting is that they also adopt a 'food system' approach, so they discuss challenges and potential solutions along the food chain, from production to consumption, as well as food wastage. Kuokkanen et al. (2017) also use an integrated approach in their analysis of the food system lock-in in the Finnish context. They examine the impacts of the 'irreversible' transformation of food system induced by the introduction of synthetic nitrogen and phosphorus fertilizers, among others, to the Finnish food system. They also consider the positive and negative implications of the created system lock-in for long-term food security. Systematic resistance towards sustainability transition is analysed in interdependent production, policy and institutional, and supply chain processes. Levidow (2015) uses the 'bioeconomy' and 'sustainable intensification' (neoproductivism) agendas to illustrate a nascent 'corporateenvironmental food regime' and relates these two agendas to agroecology. In the process, he also discusses how these two agendas operate in relation to achieving sustainable food security in Europe. Likewise, Raman and Mohr (2014) work at the intersection of food and energy regimes. They analyse the controversy regarding the development of biofuels (and bioenergy in general) and its implications for food security. While biofuels were envisioned to solve problems faced by the energy regime, they generated food security-related concerns. The authors show that food-versus-fuel conflict is a symptom of linkages between globalised industrial agricultural systems and biofuels.

Three perspectives on achieving food security: efficiency, demand restraint and food system transformation

In general, papers that focus on eating practices and consumption patterns use a demand-restraint perspective. However, it should be pointed out that the three perspectives are not mutually exclusive; they are sometimes used in the same context and, consequently, discussed in the same papers. For instance, Pant (2016) analyses the paradox of mainstreaming agroecology (cf. food system transformation perspective) for crop intensification (cf. efficiency perspective). Likewise, Ely et al. (2016) compare agricultural intensification (cf. efficiency perspective) with agroecology (cf. food system transformation perspective) and relate both pathways to changes in maize consumption patterns (cf. demandrestraint perspective). In addition, Levidow (2015) highlights tensions between agroecology and the 'sustainable intensification' neo-productivist narrative in Europe. Davies (2014) relates the 'productivist' paradigm (see, use of technology, in particular ICT) to food-eating practices in urban settings, and points out that technological advances in production (cf. efficiency perspective) alone are unlikely to generate the radical transformation required to move toward more sustainable urban foodscapes. Similarly, the example of biofuels (Raman and Mohr 2014) shows clearly that improving production 
efficiency does not automatically yield improvements in terms of food system sustainability and food security, as the production is not destined for human consumption. Liu et al. (2016) show that efficient production technology (cf. efficiency perspective) is used in China as an entry point to move towards sustainable food consumption (cf. demand-restraint perspective). Other scholars (Kuokkanen et al. 2017; Randelli and Rocchi 2017) highlight the importance of connecting consumption and production, and point out that only an interactive and balanced relation between consumers and producers can foster the needed agro-food sustainability transition. In doing so, they implicitly highlight the need for a food system approach.

Only a few papers adopt a 'food system' approach (Chiffoleau et al. 2016; Ely et al. 2016; Jurgilevich et al. 2016; Kuokkanen et al. 2017; Marsden 2013; van Gameren et al. 2015; Vittersø and Tangeland 2015), that can be related to the 'food system transformation' perspective, although many scholars refer to the 'food system' concept (Audet et al. 2017; Chiffoleau et al. 2016; Cohen and Ilieva 2015; Crivits and Paredis 2013; Dedeurwaerdere et al. 2017; Ely et al. 2016; Jehlička and Smith 2011; Jurgilevich et al. 2016; Kuokkanen et al. 2017; Lutz and Schachinger 2013; Rossi 2017; van Gameren et al. 2015; Vittersø and Tangeland 2015). Different alternative forms of agriculture (e.g. organic agriculture, urban agriculture, permaculture) adopt more systemic approaches and promote synergetic connections between system components (e.g. soils, crops, livestock, humans). Such alternative food systems/networks adopt a holistic approach to food production and strive to connect consumption and production (Cerrada-Serra et al. 2018; Jarosz 2008) by, among others, promoting short food supply chains (Chiffoleau et al. 2016). These alternative approaches include food sovereignty and agroecology (Levidow 2015; Lutz and Schachinger 2013). In fact, the transformative potential of agroecology is increasingly recognised (FAO 2015; IAASTD 2008; IPES-Food 2016), and is promoted as a way of transforming and redesigning food systems, from the farm to the fork (Gliessman 2015, 2016). Instead of the earlier focus on and critique of intensive production and agriculture industrialisation, the current agro-ecological thinking criticises the whole agro-food regime (Elzen et al. 2017; Gliessman and Engles 2015; Holt-Giménez and Altieri 2013).

\subsection{Nutrition}

Generally speaking, all papers that address aspects of food consumption deal with nutrition (Chiffoleau et al. 2016; Clear et al. 2016; Cohen and Ilieva 2015; Dedeurwaerdere et al. 2017; Liu et al. 2016; Mylan et al. 2016; Rossi 2017; Stahlbrand 2016). Interestingly, there is also a correspondence between focus on nutrition and reference analytical framework. In fact, almost all these papers refer to the Social
Practice Theory/Approach (SPT/SPA) (e.g. Shove 2003; Southerton et al. 2004; Warde 2005). As well, papers that adopt a 'food system' approach (Jurgilevich et al. 2016; Kuokkanen et al. 2017) address issues related to food consumption and nutrition. In general, it is assumed that transitions toward sustainable food systems imply changes in food consumption patterns and dietary habits (e.g. Twine 2015). Some scholars argue that health/nutrition-related concerns (e.g. food safety, obesity) may represent a good entry point to bringing about a deep and genuine food transformation that puts sustainability at the forefront (Davidson et al. 2016).

Davidson et al. (2016) analyse linkages between food safety risks (cf. bovine spongiform encephalopathy or mad cow disease) and sustainability transition in beef production in the province of Alberta (Canada). In so doing, they show that not only consumers' perceptions and attitude towards sustainability, but also their nutrition concerns, can be drivers of sustainability transition journeys, especially in relation to alternative food networks/systems. Ferguson (2016) uses the example of the Australian baking industry to show that while sustainability transitions in the baking sector may bring about health and nutritional benefits (small-scale artisan bakers produce more nutritious products), they may also lead to an overall decline in productivity across the whole sector. This example clearly shows trade-offs between the different dimensions of food sustainability (environment, economy, society-culture, health-nutrition) (e.g. Dernini et al. 2013) during the transition process. Twine (2015) contributes to sociological thinking on eating practices and their reproduction by providing an analysis of snacking through a practice theory lens. He situates snacking as an eating practice with health implications that has emerged within the organization of everyday life. In fact, 'A snack has typically been seen as less nutritionally adequate than a meal" (p. 1275) and consistently snacking at mealtimes goes against prevailing nutritional norms and common eating practices. Vinnari and Vinnari (2014) develop a transition management framework and apply it to the case of plant-based diets, which are considered as sustainable diets. They also highlight the main obstacles to a transition towards plant-based diets, which have social, economic, environmental, cultural and animal (cf. animal welfare/rights) dimensions.

\subsection{Food security and nutrition}

Only a few papers address food security and nutrition security aspects at the same time. These are mainly the ones that address issues regarding the whole food system (see, 'food system approach') as well as those that deal with food consumption patterns and practices (Chiffoleau et al. 2016; Clear et al. 2016; Cohen and Ilieva 2015; Dedeurwaerdere et al. 2017; Jurgilevich et al. 2016; Kuokkanen et al. 2017; Liu et al. 2016; Mylan et al. 2016; Rossi 2017; Stahlbrand 2016). In 
fact, all papers that deal with food utilisation/use pillar of food security also address aspects of food consumption and, consequently, nutrition (Chiffoleau et al. 2016; Clear et al. 2016; Cohen and Ilieva 2015; Dedeurwaerdere et al. 2017; Liu et al. 2016; Mylan et al. 2016; Rossi 2017; Stahlbrand 2016). For instance, Liu et al. (2016) propose applying the social practices approach (SPA), which combines both human agency ('individualist' perspective) and social structures (system or structural perspective), to better understand transitions toward the sustainability of food consumption patterns in China. The analysis shows that the focus is still on improving the efficiency of production technology, while little or no attention is paid to consumers' behaviour and consumption patterns. In other words, production is used as an entry point to improving food system sustainability. Therefore, the authors propose placing more emphasis on the link between food production/provision and sustainable consumption. This is a common denominator of all papers that address food security and nutrition simultaneously.

\subsection{Study limitations}

As in any systematic review, the results were affected by the search process. First, the choice of the Scopus database means that some important pieces of research in the field that are not scholarly in nature, and/or that are not indexed in Scopus (e.g. papers abstracted only in the Web of Science, book chapters, reports), were not considered. Second, the choice of search terms also affects the results, and this systematic review was no exception in this regard, although an effort was made to use different synonyms in order to broaden the initial screening basis before proceeding to a meticulous scrutiny of screened documents.

Furthermore, the research field of agro-food sustainability transitions has not reached maturity and is largely ill-defined (at least with respect to other sectors such as energy). Therefore, any endeavour to grasp it implies a certain dose of subjectivity and approximation; more research is needed in order to better delineate the contours of this nascent field. That said, the merit of this work is that it is the first of its kind and sets a baseline for future studies on agro-food sustainability transitions.

While the present study engages mainly with literature using the transition theory repertoire (especially transition frameworks such as the Multi-Level Perspective, Transition Management and Strategic Niche Management), the scholarship on agro-food sustainability is much broader and more variegated; the contribution of other theoretical approaches and research strands (e.g. political economy, ecological modernisation, economic geography, governance, resilience, socio-ecological transformation) to agro-food sustainability transitions research should be acknowledged.
Last but not least, the present paper focuses only on the analysis of whether and how transitions research on agro-food sustainability addresses food security. For a more comprehensive analysis of the multifaceted and multidimensional relation between food security and agro-food sustainability transitions, it is also necessary to investigate whether the literature on food security addresses agro-food sustainability transitions.

\section{Conclusions}

To the best of my knowledge, this is the first systematic review-based paper that delineates the contours of research on agro-food sustainability transitions and analyses how it addresses food security and nutrition. The paper confirms the marginality of agro-food in the sustainability transitions field. Most of the research to date focuses on crops and the production stage (other agriculture subsectors such as animal production and fisheries, as well as the food processing and distribution stages, are underrepresented). Furthermore, food security and nutrition are still marginal topics in papers dealing with agro-food sustainability transitions. Generally speaking, the case study approach that characterises sustainability transitions research, means that even papers that address the implications of transition in terms of food security and/or nutrition do so on a local scale, for a small number of people or a specific category of food chain actors (e.g. farmers, consumers). There is almost a complete lack of studies that address broader implications. The disconnect between food security and nutrition scholarship, on the one hand, and agrofood sustainability transitions literature, on the other hand, might be due, inter alia, to the fact that while food security and nutrition are better assessed at household and individual level, respectively, research on agro-food sustainability transitions focuses on systemic change at larger scales. This disconnect may be further explained by the limited role of agency (i.e. the role of agents) in the sustainability transitions field, while food security and nutrition concepts are, by definition, 'people-centred'. Although scholars agree that a 'food system transformation' perspective should frame and guide agro-food sustainability transitions, such a perspective is the exception rather than the rule in the field. All in all, it seems that agrofood sustainability transitions research focuses more on the 'transition' component of 'sustainability transitions', thus overlooking sustainability outcomes and impacts such as food and nutrition security.

The 2030 Agenda for Sustainable Development clearly shows that transition towards sustainable food systems is crucial to achieving sustainable development. Such a transition is also vital to achieving sustainable food and nutrition security for present and future generations. A better understanding of the linkages between agro-food system sustainability (and consequently agro-food sustainability transitions) and food 
security is necessary to achieve the second Sustainable Development Goal (SDG 2), 'Zero Hunger' (End hunger, achieve food security and improved nutrition and promote sustainable agriculture) in the context of the 2030 Agenda. Any transition in food systems-i.e. moving beyond efficiency-oriented and demand restraint narratives towards a genuine food system transformation perspective- should have as a main goal the achievement of sustainable food security and improved nutrition for all. New tools and approaches, as well as a 'thinking transition' and different thinking about agro-food sustainability transitions, are clearly needed to ensure both food security and food sustainability. Therefore, research on agro-food sustainability transitions has a vital role to play by paying more attention to food security and nutrition and addressing interrelations between agricultural production and food consumption.

Funding Information Open access funding provided by University of Natural Resources and Life Sciences Vienna (BOKU).

\section{Compliance with ethical standards}

Conflict of interest The author declares that he has no conflict of interest.

Open Access This article is distributed under the terms of the Creative Commons Attribution 4.0 International License (http:// creativecommons.org/licenses/by/4.0/), which permits unrestricted use, distribution, and reproduction in any medium, provided you give appropriate credit to the original author(s) and the source, provide a link to the Creative Commons license, and indicate if changes were made.

\section{References}

Allen, S., \& de Brauw, A. (2018). Nutrition sensitive value chains: Theory, progress, and open questions. Global Food Security, 16, 22-28. https://doi.org/10.1016/j.gfs.2017.07.002.

Alrøe, H., Sautier, M., Legun, K., Whitehead, J., Noe, E., Moller, H., \& Manhire, J. (2017). Performance versus values in sustainability transformation of food systems. Sustainability, 9(3), 332. https:// doi.org/10.3390/su9030332.

Anonymous. (2005). The Giessen declaration. Public Health Nutrition, 8(6a), 783-786. https://doi.org/10.1079/PHN2005768.

Audet, R., Lefèvre, S., Brisebois, É., \& El-Jed, M. (2017). Structuring tensions and key relations of Montreal seasonal food Markets in the Sustainability Transition of the Agri-food sector. Sustainability, 9(3), 320. https://doi.org/10.3390/su9030320.

Beddington, J., Asaduzzaman, M., Clark, M., Fernández, A., Guillou, M., Jahn, M., et al. (2012). Achieving food security in the face of climate change. Copenhagen: CGIAR Research Program on Climate Change, Agriculture and Food Security (CCAFS).

Beers, P. J., Veldkamp, A., Hermans, F., van Apeldoorn, D., Vervoort, J. M., \& Kok, K. (2010). Future sustainability and images. Futures, 42(7), 723-732. https://doi.org/10.1016/j.futures.2010.04.017.

Beers, P. J., Hermans, F., Veldkamp, T., \& Hinssen, J. (2014). Social learning inside and outside transition projects: Playing free jazz for a heavy metal audience. NJAS - Wageningen Journal of Life Sciences, 69, 5-13. https://doi.org/10.1016/j.njas.2013.10.001.

Bergek, A., Jacobsson, S., Carlsson, B., Lindmark, S., \& Rickne, A. (2008). Analyzing the functional dynamics of technological innovation systems: A scheme of analysis. Research Policy, 37(3), 407429. https://doi.org/10.1016/j.respol.2007.12.003.

Berry, E. M., Dernini, S., Burlingame, B., Meybeck, A., \& Conforti, P. (2015). Food security and sustainability: Can one exist without the other? Public Health Nutrition, 18(13), 2293-2302. https://doi.org/ 10.1017/S136898001500021X.

Bhattarai, K., \& Pant, L. (2013). Patriarchal bargains in protected spaces: A new strategy for agricultural and rural development innovation in the western hills of Nepal. Canadian Journal of Development Studies, 34(4), 461-481. https://doi.org/10.1080/02255189.2013. 830967.

Bonomi, S., Ricciardi, F., \& Rossignoli, C. (2017). Network organisations for externality challenges: How social entrepreneurship coevolves with ICT-enabled solutions. International Journal of Knowledge-Based Development, 8(4), 346-366. https://doi.org/10. 1504/IJKBD.2017.088183.

Bui, S., Cardona, A., Lamine, C., \& Cerf, M. (2016). Sustainability transitions: Insights on processes of niche-regime interaction and regime reconfiguration in Agri-food systems. Journal of Rural Studies, 48, 92-103. https://doi.org/10.1016/j.jrurstud.2016.10.003.

Bureau, J.-C., \& Swinnen, J. (2018). EU policies and global food security. Global Food Security, 16, 106-115. https://doi.org/10.1016/j.gfs. 2017.12.001.

Bush, S. R., \& Marschke, M. J. (2014). Making social sense of aquaculture transitions. Ecology and Society, 19(3), art50. https://doi.org/10. 5751/ES-06677-190350.

Candel, J. J. L., \& Biesbroek, R. (2018). Policy integration in the EU governance of global food security. Food Security, 10(1), 195-209. https://doi.org/10.1007/s12571-017-0752-5.

Capone, R., El Bilali, H., Debs, P., Cardone, G., \& Driouech, N. (2014). Food system sustainability and food security: Connecting the dots. Journal of Food Security, 2(1), 13-22. https://doi.org/10.12691/jfs2-1-2.

Cerrada-Serra, P., Moragues-Faus, A., Zwart, T. A., Adlerova, B., OrtizMiranda, D., \& Avermaete, T. (2018). Exploring the contribution of alternative food networks to food security. A comparative analysis. Food Security, 10(6), 1371-1388. https://doi.org/10.1007/s12571018-0860-x.

Chiffoleau, Y., Millet-Amrani, S., \& Canard, A. (2016). From short food supply chains to sustainable agriculture in urban food systems: Food democracy as a vector of transition. Agriculture, 6(4), 57. https://doi. org/10.3390/agriculture6040057.

Clear, A. K., O’Neill, K., \& Friday, A. (2015). Designing for transitions to sustainable lifestyles. Interactions, 22(3), 56-58. https://doi.org/10. $1145 / 2743034$

Clear, A. K., O’neill, K., Friday, A., \& Hazas, M. (2016). Bearing an open "Pandora's box.". ACM Transactions on Computer-Human Interaction, 23(5), 1-25. https://doi.org/10.1145/2970817.

Cohen, N., \& Ilieva, R. T. (2015). Transitioning the food system: A strategic practice management approach for cities. Environmental Innovation and Societal Transitions, 17, 199-217. https://doi.org/ 10.1016/j.eist.2015.01.003.

Committee on World Food Security. (2012). Coming to terms with terminology: Food security, nutrition security, food security and nutrition, food and nutrition security. http://www.fao.org/fsnforum/sites/ default/files/file/Terminology/MD776(CFS Coming to terms with_Terminology).pdf. Accessed 10 Nov 2017.

Costa, D. (2013). Food sustainability transitions : what citizen-consumer role for the Transition movement? Master thesis, Wageningen University and Research, Wageningen.

Crivits, M., \& Paredis, E. (2013). Designing an explanatory practice framework: Local food systems as a case. Journal of Consumer 
Culture, 13(3), 306-336. https://doi.org/10.1177/ 1469540513484321.

Crivits, M., de Krom, M. P. M., Dessein, J., \& Block, T. (2017). Discursive representation within the institutional void: The rise and fall of a governance Network on sustainable food in Belgium. Sociologia Ruralis, 58, 475-499. https://doi.org/10.1111/soru. 12162.

Cross, R., \& Ampt, P. (2017). Exploring Agroecological sustainability: Unearthing innovators and documenting a Community of Practice in Southeast Australia. Society and Natural Resources, 30(5), 585600. https://doi.org/10.1080/08941920.2016.1230915.

Cumming, G. S., Buerkert, A., Hoffmann, E. M., Schlecht, E., Von Cramon-Taubadel, S., \& Tscharntke, T. (2014). Implications of agricultural transitions and urbanization for ecosystem services. Nature, 515(7525), 50-57. https://doi.org/10.1038/nature13945.

das Chagas Oliveira, F., Calle Collado, A., \& Carvalho Leite, L. F. (2012). Peasant innovations and the search for sustainability: The case of Carnaubais territory in Piauí state, Brazil. Journal of Sustainable Agriculture, 36(5), 523-544. https://doi.org/10.1080/ 10440046.2012.656342.

Davidson, D. J., Jones, K. E., \& Parkins, J. R. (2016). Food safety risks, disruptive events and alternative beef production: A case study of agricultural transition in Alberta. Agriculture and Human Values, 33(2), 359-371. https://doi.org/10.1007/s10460-015-9609-8.

Davies, A. R. (2014). Co-creating sustainable eating futures: Technology, ICT and citizen-consumer ambivalence. Futures, 62, 181-193. https://doi.org/10.1016/j.futures.2014.04.006.

Davies, A. R., \& Doyle, R. (2015). Transforming household consumption: From Backcasting to HomeLabs experiments. Annals of the Association of American Geographers, 105(2), 425-436. https:// doi.org/10.1080/00045608.2014.1000948.

de Olde, E. M., Carsjens, G. J., \& Eilers, C. H. A. M. (2017). The role of collaborations in the development and implementation of sustainable livestock concepts in the Netherlands. International Journal of Agricultural Sustainability, 15(2), 153-168. https://doi.org/10.1080/ 14735903.2016.1193423.

Dedeurwaerdere, T., De Schutter, O., Hudon, M., Mathijs, E., Annaert, B., Avermaete, T., et al. (2017). The governance features of social Enterprise and social Network activities of collective food buying groups. Ecological Economics, 140, 123-135. https://doi.org/10. 1016/j.ecolecon.2017.04.018.

Delaney, A., Evans, T., McGreevy, J., Blekking, J., Schlachter, T., Korhonen-Kurki, K., Tamás, P. A., Crane, T. A., Eakin, H., Förch, W., Jones, L., Nelson, D. R., Oberlack, C., Purdon, M., \& Rist, S. (2018). Governance of food systems across scales in times of socialecological change: A review of indicators. Food Security, 10(2), 287-310. https://doi.org/10.1007/s12571-018-0770-y.

Dentoni, D., Waddell, S., \& Waddock, S. (2017). Pathways of transformation in global food and agricultural systems: Implications from a large systems change theory perspective. Current Opinion in Environmental Sustainability, 29, 8-13. https://doi.org/10.1016/j. cosust.2017.10.003.

Dernini, S., Meybeck, A., Burlingame, B., Gitz, V., Lacirignola, C., Debs, P., et al. (2013). Developing a methodological approach for assessing the sustainability of diets: The Mediterranean diet as a case study. New Medit, 3, 28-36.

Du, J., \& King, C. (2018). Unravelling China's food security puzzle, 1979-2008. The China Quarterly, 235, 804-827. https://doi.org/ $10.1017 / \mathrm{S} 0305741018000917$.

Dumont, R., \& Rosier, B. (1969). The hungry future. London: Deutsch.

Duru, M., Fares, M., \& Therond, O. (2014). A conceptual framework for thinking now (and organising tomorrow) the agroecological transition at the level of the territory. Cahiers Agricultures, 23(2), 84-95. https://doi.org/10.1684/agr.2014.0691.
El Bilali, H. (2018a). Relation between innovation and sustainability in the agro-food system. Italian Journal of Food Science, 30, 200-225. https://doi.org/10.14674/IJFS-1096.

El Bilali, H. (2018b). Transition heuristic frameworks in research on agrofood sustainability transitions. Environment, Development and Sustainability. https://doi.org/10.1007/s10668-018-0290-0.

Ely, A., Geall, S., \& Song, Y. (2016). Sustainable maize production and consumption in China: Practices and politics in transition. Journal of Cleaner Production, 134(Part A), 259-268. https://doi.org/10.1016/ j.jclepro.2015.12.001.

Elzen, B., \& Bos, B. (2016). The RIO approach: Design and anchoring of sustainable animal husbandry systems. Technological Forecasting and Social Change. https://doi.org/10.1016/j.techfore.2016.05.023.

Elzen, B., Geels, F. W., Leeuwis, C., \& Van Mierlo, B. (2011). Normative contestation in transitions "in the making": Animal welfare concerns and system innovation in pig husbandry. Research Policy, 40(2), 263-275. https://doi.org/10.1016/j.respol.2010.09.018.

Elzen, B., Augustyn, A. M., Barbier, M., \& van Mierlo, B. (2017). AgroEcological transitions: Changes and breakthroughs in the making. https://doi.org/10.18174/407609.

Ericksen, P. J. (2008). Conceptualizing food systems for global environmental change research. Global Environmental Change, 18(1), 234 245. https://doi.org/10.1016/j.gloenvcha.2007.09.002.

European Environment Agency. (2016). Sustainability transitions: Now for the long term. Copenhagen.

Falcone, P. M. (2014). Sustainability transitions: A survey of an emerging field of research. Environmental Management and Sustainable Development, 3(2), 61. https://doi.org/10.5296/emsd.v3i2.6239.

Fanzo, J., Davis, C., McLaren, R., \& Choufani, J. (2018). The effect of climate change across food systems: Implications for nutrition outcomes. Global Food Security, 18, 12-19. https://doi.org/10.1016/j. gfs.2018.06.001.

FAO. (1996). Rome declaration on food security and world food summit plan of action. Rome.

FAO. (2009a). State of food insecurity 2009. Rome.

FAO. (2009b). Declaration of the world food summit on food security. Rome. http:/www.fao.org/tempref/docrep/fao/Meeting/018/ k6050e.pdf. Accessed 13 Oct 2017.

FAO. (2013). The state of food and agriculture - food systems for better nutrition. Rome.

FAO. (2014). Building a common vision for sustainable food and agriculture - principles and approaches. Rome.

FAO. (2015). Agroecology for food security and nutrition. Proceedings of the FAO international symposium; 18-19 September 2014, Rome. www.fao.org/3/a-i4729e.pdf. Accessed 21 Nov 2017

FAO. (2017). Nutrition-sensitive agriculture and food systems in practice - options for intervention. Rome.

FAO, \& WHO. (2014). Conference outcome document: Rome Declaration on Nutrition. Second International Conference on Nutrition, 19-21 November 2014, Rome.

FAO, IFAD, \& WFP. (2015). The State of Food Insecurity in the World 2015. Meeting the 2015 international hunger targets: Taking stock of uneven progress. Rome.

FAO, IFAD, UNICEF, WFP, \& WHO. (2017). The State of Food Security and Nutrition in the World 2017. Building resilience for peace and food security. Rome.

FAO, WFP, \& IFAD. (2013). The State of Food Insecurity in the World 2013: The Multiple Dimensions of Food Security. Rome.

Fauchald, P., Hausner, V. H., Schmidt, J. I., \& Clark, D. A. (2017). Transitions of social-ecological subsistence systems in the Arctic. International Journal of the Commons, 11(1), 275-329. https://doi. org/10.18352/ijc.698.

Ferguson, P. (2016). Productivity growth as a barrier to a sustainability transition. Environmental Innovation and Societal Transitions, 20 , 86-88. https://doi.org/10.1016/j.eist.2015.10.003. 
Ferguson, R. S., \& Lovell, S. T. (2014). Permaculture for agroecology: Design, movement, practice, and worldview. A review. Agronomy for Sustainable Development., 34, 251-274. https://doi.org/10. 1007/s13593-013-0181-6.

Fischer, A. R. H., Beers, P. J., Latesteijn, H. V., Andeweg, K., Jacobsen, E., Mommaas, H., et al. (2012). Transforum system innovation towards sustainable food. A review. Agronomy for Sustainable Development, 32(2), 595-608. https://doi.org/10.1007/s13593-0110067-4.

Foresight. (2011). The future of food and farming. Final project report. London, United Kingdom.

Friedmann, H. (2017). Paradox of transition: Two reports on how to move towards sustainable food systems. Development and Change, 48(5), 1210-1226. https://doi.org/10.1111/dech.12329.

Garnett, T. (2014). Three perspectives on sustainable food security: Efficiency, demand restraint, food system transformation. What role for life cycle assessment? Journal of Cleaner Production, 73, 10 18. https://doi.org/10.1016/j.jclepro.2013.07.045.

Garnett, T., Appleby, M. C., Balmford, A., Bateman, I. J., Benton, T. G., Bloomer, P., Burlingame, B., Dawkins, M., Dolan, L., Fraser, D., Herrero, M., Hoffmann, I., Smith, P., Thornton, P. K., Toulmin, C., Vermeulen, S. J., \& Godfray, H. C. J. (2013). Sustainable intensification in agriculture: Premises and policies. Science., 341, 33-34. https://doi.org/10.1126/science.1234485.

Gazheli, A., Antal, M., \& van den Bergh, J. (2012). Behavioural aspects of sustainability transitions. In 3rd International Conference on Sustainability Transitions; Track E "Theory Development and Critical Perspectives" (pp. 337-359). Copenhagen.

Gaziulusoy, A. I. (2015). A critical review of approaches available for design and innovation teams through the perspective of sustainability science and system innovation theories. Journal of Cleaner Production, 107, 366-377. https://doi.org/10.1016/j.jclepro.2015. 01.012 .

Geels, F. W. (2002). Technological transitions as evolutionary reconfiguration processes: A multi-level perspective and a case-study. Research Policy, 31(8-9), 1257-1274. https://doi.org/10.1016/ S0048-7333(02)00062-8.

Geels, F. W. (2011). The multi-level perspective on sustainability transitions: Responses to seven criticisms. Environmental Innovation and Societal Transitions, 1(1), 24-40. https://doi.org/10.1016/j.eist. 2011.02.002.

George, S. (1976). How the other half dies: The real reasons for world hunger. Harmondsworth: Penguin.

Ghaffari, A., Bunch, M. J., MacRae, R. J., \& Zhao, S. J. (2015). Socioeconomic support optimization for transition from conventional to organic farming using a spatiotemporal agent-based model. International Journal of Interdisciplinary Environmental Studies, $8(3-4), 13-25$.

Gilioli, G., Tikubet, G., Herren, H. R., \& Baumgärtner, J. (2015). Assessment of social-ecological transitions in a peri-urban Ethiopian farming community. International Journal of Agricultural Sustainability, 13(3), 204-221. https://doi.org/10. 1080/14735903.2014.954452.

Gitz, V. (2015). Sustainable diets and sustainable food systems. In A. Meybeck, S. Redfern, F. Paoletti, \& C. Strassner (Eds.), International workshop "assessing sustainable diets within the sustainability of food systems - Mediterranean diet, organic food: New challenges"; 15-16 September 2014, Rome (pp. 131-136). Rome: FAO.

Gladek, E., Fraser, M., Roemers, G., Sabag Munoz, O., Hirsch, P., \& Kennedy, E. (2016). The global food system: An analysis. Amsterdam. https://www.metabolic.nl/publications/global-foodsystem-analysis. 25 Oct 2017.

Gliessman, S. (2015). Agroecology: A growing field. Agroecology and Sustainable Food Systems, 39(1), 1-2. https://doi.org/10.1080/ 21683565.2014.965869.
Gliessman, S. (2016). Transforming food systems with agroecology. Agroecology and Sustainable Food Systems, 40(3), 187-189. https://doi.org/10.1080/21683565.2015.1130765.

Gliessman, S. R., \& Engles, E. W. (2015). Agroecology: The ecology of sustainable food systems. Boca Raton: CRC Press.

Godfray, H. C. J., Beddington, J. R., Crute, I. R., Haddad, L., Lawrence, D., Muir, J. F., Pretty, J., Robinson, S., Thomas, S. M., \& Toulmin, C. (2010a). Food security: The challenge of feeding 9 billion people. Science, 327(5967), 812-818. https://doi.org/10.1126/science. 1185383.

Godfray, H. C. J., Crute, I. R., Haddad, L., Lawrence, D., Muir, J. F., Nisbett, N., Pretty, J., Robinson, S., Toulmin, C., \& Whiteley, R. (2010b). The future of the global food system. Philosophical Transactions of the Royal Society of London. Series B, Biological Sciences, 365(1554), 2769-2777. https://doi.org/10.1098/rstb.2010. 0180.

Gonzalez de Molina, M. (2013). Agroecology and politics. How to get sustainability? About the Necessity for a political agroecology. Agroecology and Sustainable Food Systems, 37(1), 45-59. https:// doi.org/10.1080/10440046.2012.705810.

Gorissen, L., Spira, F., Meynaerts, E., Valkering, P., \& Frantzeskaki, N. (2018). Moving towards systemic change? Investigating acceleration dynamics of urban sustainability transitions in the Belgian City of Genk. Journal of Cleaner Production, 173, 171-185. https://doi. org/10.1016/j.jclepro.2016.12.052.

Grin, J. (2012). The politics of transition governance in Dutch agriculture. Conceptual understanding and implications for transition management. International Journal of Sustainable Development, 15(1-2), 72-89. https://doi.org/10.1504/IJSD.2012.044035.

Gross, R., Schoeneberger, H., Pfeifer, H., \& Preuss, H. J. (2000). The four dimensions of food and nutrition security: Definitions and concepts. Rome: FAO http://www.fao.org/elearning/course/FA/en/pdf/P-01 RG_Concept.pdf. Accessed 23 Oct 2017.

Halbe, J., Pahl-Wostl, C., Lange, M. A., \& Velonis, C. (2015). Governance of transitions towards sustainable development - The water-energy-food nexus in Cyprus. Water International, 40(5-6), 877-894. https://doi.org/10.1080/02508060.2015.1070328.

Hammond Wagner, C., Cox, M., \& Bazo Robles, J. L. (2016). Pesticide lock-in in small scale Peruvian agriculture. Ecological Economics, 129, 72-81. https://doi.org/10.1016/j.ecolecon.2016.05.013.

Hansen, L., \& Bjørkhaug, H. (2017). Visions and expectations for the Norwegian bioeconomy. Sustainability, 9(3), 341. https://doi.org/ $10.3390 /$ su9030341.

Hanson, C. (2013). Food security, inclusive growth, sustainability and the Post-2015 development agenda. Background paper submission to the Bali high-level panel meeting. Washington DC.

Hargreaves, T., Longhurst, N., \& Seyfang, G. (2013). Up, down, round and round: Connecting regimes and practices in innovation for sustainability. Environment and Planning A, 45(2), 402-420. https:// doi.org/10.1068/a45124.

Hassink, J., Grin, J., \& Hulsink, W. (2013). Multifunctional agriculture meets health care: Applying the multi-level transition sciences perspective to care farming in the Netherlands. Sociologia Ruralis, 53(2), 223-245. https://doi.org/10.1111/j.1467-9523.2012.00579.x.

Hassink, J., Hulsink, W., \& Grin, J. (2014). Farming with care: The evolution of care farming in the Netherlands. NJAS - Wageningen Journal of Life Sciences, 68, 1-11. https://doi.org/10.1016/j.njas. 2013.11.001.

Hassink, J., Grin, J., \& Hulsink, W. (2018). Enriching the multi-level perspective by better understanding agency and challenges associated with interactions across system boundaries. The case of care farming in the Netherlands: Multifunctional agriculture meets health care. Journal of Rural Studies, 57, 186-196. https://doi.org/10.1016/ j.jrurstud.2017.12.018.

Hauser, M., \& Lindtner, M. (2017). Organic agriculture in post-war Uganda: Emergence of pioneer-led niches between 1986 and 
1993. Renewable Agriculture and Food Systems, 32(2), 169-178. https://doi.org/10.1017/S1742170516000132.

Hekkert, M. P., Suurs, R. A. A., Negro, S. O., Kuhlmann, S., \& Smits, R. E. H. M. (2007). Functions of innovation systems: A new approach for analysing technological change. Technological Forecasting and Social Change, 74(4), 413-432. https://doi.org/10.1016/j.techfore. 2006.03.002.

Hermans, F., Van Apeldoorn, D., Stuiver, M., \& Kok, K. (2013). Niches and networks: Explaining network evolution through niche formation processes. Research Policy, 42(3), 613-623. https://doi.org/10. 1016/j.respol.2012.10.004.

Hermans, F., Roep, D., \& Klerkx, L. (2016). Scale dynamics of grassroots innovations through parallel pathways of transformative change. Ecological Economics, 130, 285-295. https://doi.org/10.1016/j. ecolecon.2016.07.011.

Hinrichs, C. C. (2014). Transitions to sustainability: A change in thinking about food systems change? Agriculture and Human Values, 31(1), 143-155. https://doi.org/10.1007/s10460-014-9479-5.

HLPE. (2014a). Food losses and waste in the context of sustainable food systems. A Report by the High Level Panel of Experts on Food Security and Nutrition (HLPE) of the Committee on World Food Security. Rome. http://www.fao.org/3/a-i3901e.pdf. Accessed 26 Nov 2017

HLPE. (2014b). Note on critical and emerging issues for food security and nutrition. Rome. http://www.fao.org/fileadmin/user_upload/ hlpe/hlpe_documents/HLPE_Reports/HLPE_Note-to-CFS Critical-and-Emerging-Issues_6-August-2014.pdf. Accessed 12 May 2015.

HLPE. (2017). Nutrition and food systems. A Report by the High Level Panel of Experts on Food Security and Nutrition (HLPE) of the Committee on World Food Security. Rome. www.fao.org/3/ai7846e.pdf. Accessed 16 Jan 2018

Holt-Giménez, E., \& Altieri, M. (2013). Agroecology, food sovereignty and the new green revolution. Journal of Sustainable Agriculture, 37, 90-102. https://doi.org/10.1080/10440046.2012.716388.

Hoppe, T., Kuokkanen, A., Mikkilä, M., Kahiluoto, H., Kuisma, M., Arentsen, M., \& Linnanen, L. (2016). System merits or failures? Policies for transition to sustainable $\mathrm{P}$ and $\mathrm{N}$ systems in the Netherlands and Finland. Sustainability, 8(5). https://doi.org/10. 3390/su8050463.

Hubeau, M., Marchand, F., Coteur, I., Mondelaers, K., Debruyne, L., \& Van Huylenbroeck, G. (2017). A new Agri-food systems sustainability approach to identify shared transformation pathways towards sustainability. Ecological Economics, 131, 52-63. https://doi.org/ 10.1016/j.ecolecon.2016.08.019.

Huttunen, S., \& Oosterveer, P. (2017). Transition to sustainable fertilisation in agriculture, a practices approach. Sociologia Ruralis, 57(2), 191-210. https://doi.org/10.1111/soru.12118.

IAASTD. (2008). Global report and synthesis report. International assessment of agricultural science and technology development knowledge. London: United Kingdom.

Immink, V. M., Reinders, M. J., Van Tulder, R. J. M., \& Van Trijp, J. C. M. (2013). The livestock sector and its stakeholders in the search to meet the animal welfare requirements of society. Journal on Chain and Network Science, 13(2), 151-160. https://doi.org/10.3920/ JCNS2013.1005.

Ingram, J. S. I. (2011a). From food production to food security: Developing interdisciplinary, regional-level research. Wageningen University, Wageningen. Retrieved from http://edepot.wur.nl/ 176450. Accessed 21 Oct 2017

Ingram, J. (2011b). A food systems approach to researching food security and its interactions with global environmental change. Food Security, 3(4), 417-431. https://doi.org/10.1007/s12571-011-01499.

Ingram, J. (2015). Framing niche-regime linkage as adaptation: An analysis of learning and innovation networks for sustainable agriculture across Europe. Journal of Rural Studies, 40, 59-75. https://doi.org/ 10.1016/j.jrurstud.2015.06.003.

Ingram, J., Maye, D., Kirwan, J., Curry, N., \& Kubinakova, K. (2015). Interactions between niche and regime: An analysis of learning and innovation networks for sustainable agriculture across Europe. Journal of Agricultural Education and Extension, 21(1), 55-71. https://doi.org/10.1080/1389224X.2014.991114.

IPES-Food. (2015). The new science of sustainable food systems: Overcoming barriers to food systems reform. International panel of experts on sustainable food systems. www.ipes-food.org/ images/Reports/IPES_report01_1505_web_br_pages.pdf. Accessed 13 Mar 2016

IPES-Food. (2016). From uniformity to diversity: A paradigm shift from industrial agriculture to diversified agroecological systems. International panel of experts on sustainable food systems. www. ipes-food.org/images/Reports/UniformityToDiversity FullReport. pdf. Accessed 22 Oct 2017.

Isgren, E., \& Ness, B. (2017). Agroecology to promote just sustainability transitions: Analysis of a civil society network in the Rwenzori region, western Uganda. Sustainability, 9(8). https://doi.org/10. 3390/su9081357.

Jacobs, B., Cordell, D., Chin, J., \& Rowe, H. (2017). Towards phosphorus sustainability in North America: A model for transformational change. Environmental Science and Policy, 77, 151-159. https://doi. org/10.1016/j.envsci.2017.08.009.

Järnberg, L., Enfors Kautsky, E., Dagerskog, L., \& Olsson, P. (2018). Green niche actors navigating an opaque opportunity context: Prospects for a sustainable transformation of Ethiopian agriculture. Land Use Policy, 71, 409-421. https://doi.org/10.1016/j.landusepol. 2017.11.053.

Jarosz, L. (2008). The city in the country: Growing alternative food networks in metropolitan areas. Journal of Rural Studies., 24, 231-244. https://doi.org/10.1016/j.jrurstud.2007.10.002.

Jehlička, P., \& Smith, J. (2011). An unsustainable state: Contrasting food practices and state policies in the Czech Republic. Geoforum, 42(3), 362-372. https://doi.org/10.1016/j.geoforum.2011.01.005.

Jurgilevich, A., Birge, T., Kentala-Lehtonen, J., Korhonen-Kurki, K., Pietikäinen, J., Saikku, L., \& Schösler, H. (2016). Transition towards circular economy in the food system. Sustainability, 8(1), 1-14. https://doi.org/10.3390/su8010069.

Konefal, J. (2015). Governing sustainability transitions: Multistakeholder initiatives and regime change in United States agriculture. Sustainability, 7(1), 612-633. https://doi.org/10.3390/ su7010612.

Kovács, B. (2011). Transition towards sustainable food consumption and production in a resource constrained world. EuroChoices, 10(2), 44-47. https://doi.org/10.1111/j.1746-692X.2011.00202.x.

Kuhmonen, T. (2017). Exposing the attractors of evolving complex adaptive systems by utilising futures images: Milestones of the food sustainability journey. Technological Forecasting and Social Change, 114, 214-225. https://doi.org/10.1016/j.techfore.2016.08. 015.

Kuokkanen, A., Mikkilä, M., Kuisma, M., Kahiluoto, H., \& Linnanen, L. (2017). The need for policy to address the food system lock-in: A case study of the Finnish context. Journal of Cleaner Production, 140, 933-944. https://doi.org/10.1016/j.jclepro.2016.06.171.

Lachman, D. A. (2013). A survey and review of approaches to study transitions. Energy Policy, 58, 269-276. https://doi.org/10.1016/j. enpol.2013.03.013.

Lang, T. (2009). Food security and sustainability: The perfect fit. Sustainable Development Commission (SDC): London, United Kingdom.

Lang, T., \& Barling, D. (2012). Food security and food sustainability: Reformulating the debate. The Geographical Journal, 178(4), 313326. https://doi.org/10.1111/j.1475-4959.2012.00480.x. 
Lang, T., \& Barling, D. (2013). Nutrition and sustainability: An emerging food policy discourse. Proceedings of the Nutrition Society, 72(01), 1-12. https://doi.org/10.1017/S002966511200290X.

Langendahl, P.-A., Cook, M., \& Potter, S. (2016). Sustainable innovation journeys: Exploring the dynamics of firm practices as part of transitions to more sustainable food and farming. Local Environment, 21(1), 105-123. https://doi.org/10.1080/13549839.2014.926869.

Lawhon, M., \& Murphy, J. T. (2012). Socio-technical regimes and sustainability transitions: Insights from political ecology. Progress in Human Geography, 36(3), 354-378. https://doi.org/10.1177/ 0309132511427960.

Lebel, L., Lebel, P., Garden, P., Giap, D. H., Khrutmuang, S., \& Nakayama, S. (2008). Places, chains, and plates: Governing transitions in the shrimp aquaculture production-consumption system. Globalizations, 5(2), 211-226. https://doi.org/10.1080/ 14747730802057589.

Leitzmann, C., \& Cannon, G. (2005). Dimensions, domains and principles of the new nutrition science. Public Health Nutrition, 8(6A), 787-794. https://doi.org/10.1079/PHN2005821.

Levidow, L. (2015). European transitions towards a corporateenvironmental food regime: Agroecological incorporation or contestation? Journal of Rural Studies, 40, 76-89. https://doi.org/10. 1016/j.jrurstud.2015.06.001.

Levidow, L., Pimbert, M., \& Vanloqueren, G. (2014). Agroecological research: Conforming - Or transforming the dominant agro-food regime? Agroecology and Sustainable Food Systems, 38(10), 1127-1155. https://doi.org/10.1080/21683565.2014.951459.

Levkoe, C. Z. (2011). Towards a transformative food politics. Local Environment, 16(7), 687-705. https://doi.org/10.1080/13549839. 2011.592182

Libert, B. (1997). The transition of Baltic agriculture. Ambio, 26(7), 473 475.

Liu, W., Oosterveer, P., \& Spaargaren, G. (2016). Promoting sustainable consumption in China: A conceptual framework and research review. Journal of Cleaner Production, 134, 13-21. https://doi.org/ 10.1016/j.jclepro.2015.10.124.

Loconto, A., \& Barbier, M. (2017). Creating actionable knowledge for sustainability: A case of "standards in the making". In Transforming the rural (research in rural sociology and development, volume 24) (pp. 115-133). Emerald Publishing Limited. https://doi.org/10. 1108/S1057-192220170000024006.

Long, T. B., Blok, V., \& Coninx, I. (2016). Barriers to the adoption and diffusion of technological innovations for climate-smart agriculture in Europe: Evidence from the Netherlands, France, Switzerland and Italy. Journal of Cleaner Production, 112, 9-21. https://doi.org/10. 1016/j.jclepro.2015.06.044.

Long, T. B., Looijen, A., \& Blok, V. (2018). Critical success factors for the transition to business models for sustainability in the food and beverage industry in the Netherlands. Journal of Cleaner Production, 175, 82-95. https://doi.org/10.1016/j.jclepro.2017.11. 067.

Loorbach, D. (2010). Transition management for sustainable development: A prescriptive, complexity-based governance framework. Governance, 23(1), 161-183. https://doi.org/10.1111/j.1468-0491. 2009.01471.x.

Loorbach, D., \& Rotmans, J. (2006). Managing transitions for sustainable development. In X. Olshoorn \& A. J. Wieczorek (Eds.), Understanding industrial transformation. Views from different disciplines. Dordrecht: Springer.

Loorbach, D., \& Rotmans, J. (2010). Transition management and strategic niche management. Rotterdam: Dutch Research Institute for Transitions.

Loorbach, D., Van Der Brugge, R., \& Taanman, M. (2008). Governance in the energy transition: Practice of transition management in the Netherlands. International Journal of Environmental Technology and Management, 9(2/3), 294. https://doi.org/10.1504/IJETM. 2008.019039.

Lutz, J., \& Schachinger, J. (2013). Do local food networks foster socioecological transitions towards food sovereignty? Learning from real place experiences. Sustainability, 5(11), 4778-4796. https://doi.org/ $10.3390 /$ su5 114778

Manuel-Navarrete, D., \& Gallopín, G. C. (2012). Feeding the world sustainably: Knowledge governance and sustainable agriculture in the argentine pampas. Environment, Development and Sustainability, 14(3), 321-333. https://doi.org/10.1007/s10668-011-9326-4.

Marco, I., Padró, R., Cattaneo, C., Caravaca, J., \& Tello, E. (2017). From vineyards to feedlots: A fund-flow scanning of sociometabolic transition in the Vallès County (Catalonia) 1860-1956-1999. Regional Environmental Change, 18, 1-13. https://doi.org/10.1007/s10113017-1172-y.

Markard, J., Raven, R., \& Truffer, B. (2012). Sustainability transitions: An emerging field of research and its prospects. Research Policy, 41(6), 955-967. https://doi.org/10.1016/j.respol.2012.02.013.

Marsden, T. (2013). From post-productionism to reflexive governance: Contested transitions in securing more sustainable food futures. Journal of Rural Studies, 29, 123-134. https://doi.org/10.1016/j. jrurstud.2011.10.001.

Marsden, T., Hebinck, P., \& Mathijs, E. (2018). Re-building food systems: Embedding assemblages, infrastructures and reflexive governance for food systems transformations in Europe. Food Security, 10(6), 1301-1309. https://doi.org/10.1007/s12571-018-0870-8.

Maru, Y., Sparrow, A., Stirzaker, R., \& Davies, J. (2016). Integrated agricultural research for development (IAR4D) from a theory of change perspective. Agricultural Systems, 165, 310-320. https:// doi.org/10.1016/j.agsy.2016.09.012.

Maye, D. (2018). Examining innovation for sustainability from the bottom up: An analysis of the permaculture Community in England. Sociologia Ruralis, 58(2), 331-350. https://doi.org/10.1111/soru. 12141 .

Maye, D., \& Duncan, J. (2017). Understanding sustainable food system transitions: Practice, assessment and governance. Sociologia Ruralis, 57(3), 267-273. https://doi.org/10.1111/soru.12177.

McMichael, P. (2014). Rethinking 'food security' for the new millennium: Sage advice. Sociologia Ruralis, 54(1), 109-111. https://doi. org/10.1111/soru.12038.

Meek, D. (2016). The cultural politics of the agroecological transition. Agriculture and Human Values, 33(2), 275-290. https://doi.org/10. 1007/s10460-015-9605-z.

Meynard, J.-M., Jeuffroy, M.-H., Le Bail, M., Lefèvre, A., Magrini, M.B., \& Michon, C. (2017). Designing coupled innovations for the sustainability transition of agrifood systems. Agricultural Systems, 157, 330-339. https://doi.org/10.1016/j.agsy.2016.08.002.

Miles, A., DeLonge, M. S., \& Carlisle, L. (2017). Triggering a positive research and policy feedback cycle to support a transition to agroecology and sustainable food systems. Agroecology and Sustainable Food Systems, 41(7), 855-879. https://doi.org/10.1080/21683565. 2017.1331179 .

Minh, T. T., Friederichsen, R., Neef, A., \& Hoffmann, V. (2014). Niche action and system harmonization for institutional change: Prospects for demand-driven agricultural extension in Vietnam. Journal of Rural Studies, 36, 273-284. https://doi.org/10.1016/j.jrurstud. 2014.09.008

Moher, D., Liberati, A., Tetzlaff, J., Altman, D. G., \& The PRISMA Group. (2009). Preferred reporting items for systematic reviews and meta-analyses: The PRISMA statement. PLoS Medicine, 6(7), e1000097. https://doi.org/10.1371/journal.pmed.1000097.

Moragues-Faus, A., \& Morgan, K. (2015). Reframing the foodscape: The emergent world of urban food policy. Environment and Planning A, 47(7), 1558-1573. https://doi.org/10.1177/0308518X15595754.

Moraine, M., Grimaldi, J., Murgue, C., Duru, M., \& Therond, O. (2016). Co-design and assessment of cropping systems for developing crop- 
livestock integration at the territory level. Agricultural Systems, 147, 87-97. https://doi.org/10.1016/j.agsy.2016.06.002.

Morrissey, J. E., Mirosa, M., \& Abbott, M. (2014). Identifying transition capacity for Agri-food regimes: Application of the multi-level perspective for strategic mapping. Journal of Environmental Policy \& Planning, 16(2), 281-301. https://doi.org/10.1080/1523908X.2013. 845521.

Mylan, J., Holmes, H., \& Paddock, J. (2016). Re-introducing consumption to the 'circular economy': A sociotechnical analysis of domestic food provisioning. Sustainability, 8(12), 794. https://doi.org/10. 3390/su8080794.

Negi, V. S., Maikhuri, R. K., Rawat, L. S., \& Bahuguna, A. (2009). Traditional agriculture in transition: A case of Har-ki Doon Valley (Govind Pashu Vihar Sanctuary and National Park) in central Himalaya. International Journal of Sustainable Development and World Ecology, 16(5), 313-321. https://doi.org/10.1080/ 13504500903194739.

Nygaard, I., \& Bolwig, S. (2018). The rise and fall of foreign private investment in the jatropha biofuel value chain in Ghana. Environmental Science \& Policy, 84, 224-234. https://doi.org/10. 1016/j.envsci.2017.08.007 .

O'Rourke, D., \& Lollo, N. (2015). Transforming consumption: From decoupling, to behavior change, to system changes for sustainable consumption. Annual Review of Environment and Resources, 40(1), 233-259. https://doi.org/10.1146/annurev-environ-102014-021224.

OECD. (2013). Global food security: Challenges for the food and agriculture system. Paris. https://doi.org/10.1787/9789264195363-en.

Paddock, J. (2017). Household consumption and environmental change: Rethinking the policy problem through narratives of food practice. Journal of Consumer Culture, 17(1), 122-139. https://doi.org/10. $1177 / 1469540515586869$.

Pant, L. P. (2014). Critical systems of learning and innovation competence for addressing complexity in transformations to agricultural sustainability. Agroecology and Sustainable Food Systems, 38(3), 336-365. https://doi.org/10.1080/21683565.2013.833157.

Pant, L. P. (2016). Paradox of mainstreaming agroecology for regional and rural food security in developing countries. Technological Forecasting and Social Change, 111, 305-316. https://doi.org/10. 1016/j.techfore.2016.03.001.

Pant, L. P., Kc, K. B., Fraser, E. D. G., Shrestha, P. K., Lama, A. B., Jirel, S. K., \& Chaudhary, P. (2014). Adaptive transition Management for Transformations to agricultural sustainability in the Karnali Mountains of Nepal. Agroecology and Sustainable Food Systems, 38(10), 1156-1183. https://doi.org/10.1080/21683565.2014. 942022.

Papachristos, G., \& Adamides, E. (2016). A retroductive systems-based methodology for socio-technical transitions research. Technological Forecasting and Social Change, 108, 1-14. https://doi.org/10.1016/ j.techfore.2016.04.007.

Partzsch, L. (2017). Biofuel research: Perceptions of power and transition. Energy, Sustainability and Society, 7(1). https://doi.org/10. 1186/s13705-017-0116-1.

Pereira, L., Karpouzoglou, T., Doshi, S., \& Frantzeskaki, N. (2015). Organising a safe space for navigating social-ecological transformations to sustainability. International Journal of Environmental Research and Public Health, 12(6), 6027-6044. https://doi.org/10. 3390/ijerph120606027.

Pinstrup-Andersen, P., \& Herforth, A. (2008). Food security: Achieving the potential. Environment: Science and Policy for Sustainable Development, 50(5), 48-61. https://doi.org/10.3200/ENVT.50.5. 48-61.

Pitt, H., \& Jones, M. (2016). Scaling up and out as a pathway for food system transitions. Sustainability, 8(10). https://doi.org/10.3390/ su8101025.

Poole, N., Echavez, C., \& Rowland, D. (2018). Are agriculture and nutrition policies and practice coherent? Stakeholder evidence from
Afghanistan. Food Security, 10(6), 1577-1601. https://doi.org/10. 1007/s12571-018-0851-y.

Prasad, S. C. (2016). Innovating at the margins: The system of rice intensification in India and transformative social innovation. Ecology and Society, 21(4). https://doi.org/10.5751/ES-08718-210407.

Prosekov, A. Y., \& Ivanova, S. A. (2018). Food security: The challenge of the present. Geoforum, 91, 73-77. https://doi.org/10.1016/j. geoforum.2018.02.030.

Prosperi, P., Allen, T., Padilla, M., \& Peri, L. (2014). New methodological frontiers for sustainability assessment: A multidimensional vulnerability framework for the agrofood system. In 50th SIDEA Conference, Sep. 2013, Lecce (Italy). Lecce: Universitas Studiorum.

Quist, J., Thissen, W., \& Vergragt, P. J. (2011). The impact and spin-off of participatory backcasting: From vision to niche. Technological Forecasting and Social Change, 78(5), 883-897. https://doi.org/ 10.1016/j.techfore.2011.01.011.

Raman, S., \& Mohr, A. (2014). Biofuels and the role of space in sustainable innovation journeys. Journal of Cleaner Production, 65, 224 233. https://doi.org/10.1016/j.jclepro.2013.07.057.

Randelli, F., \& Rocchi, B. (2017). Analysing the role of consumers within technological innovation systems: The case of alternative food networks. Environmental Innovation and Societal Transitions, 25, 94 106. https://doi.org/10.1016/j.eist.2017.01.001.

Raven, R., \& Geels, F. W. (2010). Socio-cognitive evolution in niche development: Comparative analysis of biogas development in Denmark and the Netherlands (1973-2004). Technovation, 30(2), 87-99. https://doi.org/10.1016/j.technovation.2009.08.006.

Richardson, R. B. (2010). Ecosystem services and food security: Economic perspectives on environmental sustainability. Sustainability, 2, 3520-3548. https://doi.org/10.3390/su2113520.

Rodríguez Morales, J. E., \& Rodríguez López, F. (2017). The political economy of bioenergy in the United States: A historical perspective based on scenarios of conflict and convergence. Energy Research and Social Science, 27, 141-150. https://doi.org/10.1016/j.erss. 2017.03.002.

Rosin, C. J., Legun, K. A., Campbell, H., \& Sautier, M. (2017). From compliance to co-production: Emergent forms of agency in sustainable wine production in New Zealand. Environment and Planning A, 49(12), 2780-2799. https://doi.org/10.1177/ $0308518 X 17733747$.

Rossi, A. (2017). Beyond food provisioning: The transformative potential of grassroots innovation around food. Agriculture, 7(12), 6. https:// doi.org/10.3390/agriculture7010006.

Santhanam-Martin, M., Ayre, M., \& Nettle, R. (2015). Community sustainability and agricultural landscape change: Insights into the durability and vulnerability of the productivist regime. Sustainability Science, 10(2), 207-217. https://doi.org/10.1007/s11625-014$0268-2$.

Schandl, H., Fischer-Kowalski, M., Grunbuhel, C., \& Krausmann, F. (2009). Socio-metabolic transitions in developing Asia. Technological Forecasting and Social Change, 76(2), 267-281. https://doi.org/10.1016/j.techfore.2007.12.004.

Schot, J., \& Geels, F. W. (2008). Strategic niche management and sustainable innovation journeys: Theory, findings, research agenda, and policy. Technology Analysis \& Strategic Management, 20(5), 537554. https://doi.org/10.1080/09537320802292651.

Schut, M., Klerkx, L., Sartas, M., Lamers, D., Campbell, M. M. C., Ogbonna, I., et al. (2016). Innovation platforms: Experiences with their institutional embedding in agricultural research for development. Experimental Agriculture, 52(4), 537-561. https://doi.org/ 10.1017/S001447971500023X.

Searchinger, T., Hanson, C., Ranganathan, J., Lipinski, B., Waite, R., Winterbottom, R., et al. (2013). Creating a sustainable food future: Interim findings. A menu of solutions to sustainably feed more than 9 billion people by 2050. Washington, DC: World Resources Institute 
https://www.wri.org/sites/default/files/wri13_report_4c_wrr online.pdf. Accessed 11 June 2017.

Sen, A. (1981). Poverty and famines: An essay on entitlement and deprivation. New York: Oxford University Press.

Sherwood, S. G., \& Paredes, M. (2014). Dynamics of perpetuation the politics of keeping highly toxic pesticides on the market in Ecuador. Nature and Culture, 9(1), 21-44. https://doi.org/10.3167/nc.2014. 090102.

Shove, E. (2003). Comfort, cleanliness and convenience: The social organization of normality. Oxford: Berg.

Sixt, G. N., Klerkx, L., \& Griffin, T. S. (2018). Transitions in water harvesting practices in Jordan's rainfed agricultural systems: Systemic problems and blocking mechanisms in an emerging technological innovation system. Environmental Science \& Policy, 84, 235-249. https://doi.org/10.1016/j.envsci.2017.08.010

Slingerland, M., \& Schut, M. (2014). Jatropha developments in Mozambique: Analysis of structural conditions influencing nicheregime interactions. Sustainability, 6(11), 7541-7563. https://doi. org/10.3390/su6117541

Smith, P., \& Gregory, P. J. (2013). Climate change and sustainable food production. Proceedings of the Nutrition Society, 72(01), 21-28. https://doi.org/10.1017/S0029665112002832.

Smith, J., \& Jehlička, P. (2007). Stories around food, politics and change in Poland and the Czech Republic. Transactions of the Institute of British Geographers, 32(3), 395-410. https://doi.org/10.1111/j. 1475-5661.2007.00258.x.

Southerton, D., Chappells, H., \& van Vliet, B. (2004). Sustainable consumption: The implications of changing infrastructures of provision. Cheltenham: Edward Elgar Publishing.

Spaargaren, G., Oosterveer, P., \& Loeber, A. (2013). Sustainability transitions in food consumption, retail and production. In Food practices in transition: Changing food consumption, retail and production in the age of reflexive modernity (pp. 1-30). New York: Routledge. https://doi.org/10.4324/9780203135921.

Stahlbrand, L. (2016). The food for life catering mark: Implementing the sustainability transition in university food procurement. Agriculture, 6(3), 46. https://doi.org/10.3390/agriculture6030046.

STRN. (2010). A mission statement and research agenda for the sustainability transitions research network. http://www.transitionsnetwork. org/files/STRN_research_agenda_20_August_2010(2).pdf. Accessed 18 Oct 2017.

STRN. (2016). 22nd newsletter from the steering group of the Sustainability Transitions Research Network - December 2016. h t t p : / / w w w.transitions network.org/files / 22ndSTRNnewsletter(December2016).pdf. Accessed 11 Mar 2017.

STRN. (2017). A research agenda for the sustainability transitions research Network. https://ransitionsnetwork.org/wp-content/uploads/ 2018/01/STRN Research Agenda 2017.pdf. Accessed 16 Feb 2018.

Sustainability Transitions Research Network. (2018). Newsletter 27: March 2018. https://transitionsnetwork.org/wp-content/uploads/ 2018/04/27th-STRN-newsletter-.pdf. 27 Mar 2018.

Sutherland, L.-A., Peter, S., \& Zagata, L. (2015). Conceptualising multiregime interactions: The role of the agriculture sector in renewable energy transitions. Research Policy, 44(8), 1543-1554. https://doi. org/10.1016/j.respol.2015.05.013.

Termeer, C. J. A. M., \& Dewulf, A. (2012). Towards theoretical multiplicity for the governance of transitions: The energy-producing greenhouse case. International Journal of Sustainable Development, 15(1-2), 37-53. https://doi.org/10.1504/IJSD.2012. 044033.

Thow, A. M., Greenberg, S., Hara, M., Friel, S., DuToit, A., \& Sanders, D. (2018). Improving policy coherence for food security and nutrition in South Africa: A qualitative policy analysis. Food Security, 10(4), 1105-1130. https://doi.org/10.1007/s12571-018-0813-4.
Truffer, B., \& Markard, J. (2017). Transition studies: A PhD guide into the wild. In $2^{\text {nd }} P h D s$ in Transitions Conference. Lausanne. https:// www.ethz.ch/content/dam/ethz/.../sustainability.../Truffer Markard_2017.pdf. Accessed 14 Mar 2018

Turner, J. A., Williams, T., Nicholas, G., Foote, J., Rijswijk, K., Barnard, T., Beechener, S., \& Horita, A. (2017). Triggering system innovation in agricultural innovation systems: Initial insights from a community for change in New Zealand. Outlook on Agriculture, 46(2), 125130. https://doi.org/10.1177/0030727017708500.

Twine, R. (2015). Understanding snacking through a practice theory lens. Sociology of Health \& Illness, 37(8), 1270-1284. https://doi.org/10. 1111/1467-9566.12310

Tyfield, D., Ely, A., \& Geall, S. (2015). Low carbon innovation in China: From overlooked opportunities and challenges to transitions in power relations and practices. Sustainable Development, 23(4), 206216. https://doi.org/10.1002/sd.1588.

UNEP. (2012). Avoiding future famines: Strengthening the ecological foundation of food security through sustainable food systems. A UNEP Synthesis Report. Nairobi.

UNEP. (2018). Sustainable food systems programme. http://web.unep. org/10yfp/programmes/sustainable-food-systems-programme. Accessed 25 Mar 2018.

United Nations System High Level Task Force on Global Food Security. (2011). Food and nutrition security: Comprehensive framework for action. Summary of the Updated Comprehensive Framework for Action (UCFA). Rome.

UNSCN. (2016). Investments for healthy food systems. a framework for analysis and review of evidence on food systems investments for improving nutrition. Geneva.

UNSCN. (2017). By 2030, end all forms of malnutrition and leave no one behind. Geneva.

van den Heiligenberg, H. A. R. M., Heimeriks, G. J., Hekkert, M. P., \& van Oort, F. G. (2017). A habitat for sustainability experiments: Success factors for innovations in their local and regional contexts. Journal of Cleaner Production, 169, 204-215. https://doi.org/10. 1016/j.jclepro.2017.06.177.

van Gameren, V., Ruwet, C., \& Bauler, T. (2015). Towards a governance of sustainable consumption transitions: How institutional factors influence emerging local food systems in Belgium. Local Environment, 20(8), 874-891. https://doi.org/10.1080/13549839. 2013.872090.

van Mierlo, B., Janssen, A., Leenstra, F., \& van Weeghel, E. (2013). Encouraging system learning in two poultry subsectors. Agricultural Systems, 115, 29-40. https://doi.org/10.1016/j.agsy. 2012.10.002

Vankeerberghen, A., \& Stassart, P. M. (2016). The transition to conservation agriculture: An insularization process towards sustainability. International Journal of Agricultural Sustainability, 14(4), 392407. https://doi.org/10.1080/14735903.2016.1141561.

Vermeulen, S. J., Campbell, B. M., \& Ingram, J. S. I. (2012). Climate change and food systems. Annual Review of Environment and Resources., 37, 195-222. https://doi.org/10.1146/annurev-environ020411-130608.

Vinnari, M., \& Vinnari, E. (2014). A framework for sustainability transition: The case of plant-based diets. Journal of Agricultural and Environmental Ethics, 27(3), 369-396. https://doi.org/10.1007/ s10806-013-9468-5.

Vittersø, G., \& Tangeland, T. (2015). The role of consumers in transitions towards sustainable food consumption. The case of organic food in Norway. Journal of Cleaner Production, 92, 91-99. https://doi.org/ 10.1016/j.jclepro.2014.12.055.

Vivero-Pol, J. (2017). Food as commons or commodity? Exploring the links between normative valuations and Agency in Food Transition. Sustainability, 9(3), 442. https://doi.org/10.3390/su9030442.

Vlahos, G., Karanikolas, P., \& Koutsouris, A. (2017). Integrated farming in Greece: A transition-to-sustainability perspective. International 
Journal of Agricultural Resources, Governance and Ecology, 13(1), 43-59. https://doi.org/10.1504/IJARGE.2017.084033.

Warde, A. (2005). Consumption and theories of practice. Journal of Consumer Culture, 5(2), 131-153. https://doi.org/10.1177/ 1469540505053090.

Wieczorek, A. J. (2018). Sustainability transitions in developing countries: Major insights and their implications for research and policy. Environmental Science and Policy, 84, 204-216. https://doi.org/10. 1016/j.envsci.2017.08.008.

Wigboldus, S., Klerkx, L., Leeuwis, C., Schut, M., Muilerman, S., \& Jochemsen, H. (2016). Systemic perspectives on scaling agricultural innovations. A review. Agronomy for Sustainable Development, 36(3). https://doi.org/10.1007/s13593-016-0380-z.

Willett, W., Rockström, J., Loken, B., Springmann, M., Lang, T., Vermeulen, S., Garnett, T., Tilman, D., DeClerck, F., Wood, A., Jonell, M., Clark, M., Gordon, L. J., Fanzo, J., Hawkes, C., Zurayk, R., Rivera, J. A., de Vries, W., Majele Sibanda, L., Afshin, A., Chaudhary, A., Herrero, M., Agustina, R., Branca, F., Lartey, A., Fan, S., Crona, B., Fox, E., Bignet, V., Troell, M., Lindahl, T., Singh, S., Cornell, S. E., Srinath Reddy, K., Narain, S., Nishtar, S., \& Murray, C. J. L. (2019). Food in the Anthropocene: The EAT-lancet commission on healthy diets from sustainable food systems. The Lancet, 393, 447-492. https://doi.org/ 10.1016/S0140-6736(18)31788-4.

Wiskerke, J. S. C. (2003). On promising niches and constraining sociotechnical regimes: The case of Dutch wheat and bread. Environment and Planning A, 35(3), 429-448. https://doi.org/10. 1068/a3512.

Wonneck, L. A., \& Hobson, K. (2017). Practice-based spillover effects: Evidence from Calgary's municipal food and yard waste recycling pilot. Canadian Geographer, 61(3), 415-427. https://doi.org/10. 1111/cag.12391.

World Bank. (2015). Ending poverty and hunger by 2030: An agenda for the global food system. Washington DC.

WWW-UK. (2013). A 2020 vision for the global food system. Report summary. http://assets.wwf.org.uk/downloads/2020vision_food report_summary_feb2013.pdf. Accessed 11 Nov 2017
Yates, J., Manohar, S., Bhandari, S., Gersten, Z., Kalamatianou, S., \& Saleh, A. (2018). Building bridges and deconstructing pathways in agriculture, nutrition and health. Food Security, 10(3), 689-700. https://doi.org/10.1007/s12571-018-0793-4.

Zwartkruis, J., Moors, E., Farla, J., \& Van Lente, H. (2012). Agri-food in search of sustainability: Cognitive, interactional and material framing. Journal on Chain and Network Science, 12(2), 99-110. https:// doi.org/10.3920/JCNS2012.x006.

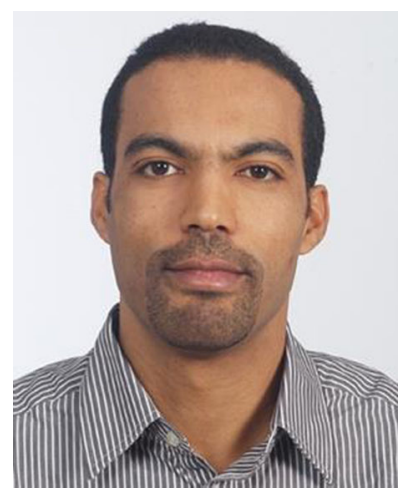

Hamid El Bilali graduated in agronomy from the Hassan II Institute of Agronomy and Veterinary Medicine (IAV Hassan-II) in Rabat, Morocco. He holds an MSc in organic agriculture (CIHEAM-Bari, 2004) and a $\mathrm{PhD}$ in agricultural sciences (University of Bari, Italy; 2008). He is currently a post-doc fellow on sustainability transitions and food security at the University of Natural Resources and Life Sciences, Vienna (BOKU). He worked for 9 years as a researcher and scientific consultant in the Sustainable Agriculture, Food and Rural Development department of the Mediterranean Agronomic Institute of Bari (CIHEAM-Bari). He has been engaged in research, training and cooperation activities relating to food security, Mediterranean diets and food consumption patterns, food losses and waste, sustainable food consumption and production, traditional and typical products, rural livelihoods diversification, and rural policy and governance. He is author of several publications (more than 140 papers and proceedings). 